\title{
Expression of Intermediate Filaments and Germ Cell Markers in the Developing Bovine Ovary: An Immunohistochemical and Laser-Assisted Microdissection Study
}

\author{
Rebecca Anna-Maria Kenngott $^{\mathrm{a}} \quad$ Ulrich Sauer $^{\mathrm{b}}$ Margarete Vermehren ${ }^{\mathrm{a}}$ \\ Fred Sinowatz ${ }^{a}$ \\ ${ }^{a}$ Institute for Anatomy, Histology, and Embryology, Department of Veterinary Sciences, Ludwig Maximilian \\ University, and ${ }^{b}$ Carl Zeiss Microscopy GmbH, Munich, Germany
}

\section{Key Words}

Ovary · Bovine $\cdot$ Development $\cdot$ Intermediate filaments .

Laser-assisted microdissection

\begin{abstract}
In the present investigation, bovine ovary prenatal development was studied using immunohistochemistry and laserassisted microdissection (LAM). A major aim of this study was to evaluate the protein expression pattern of intermediate filaments (IF) and distinguish S100 protein (S100 alpha and S100 beta protein) isoforms during prenatal follicle differentiation, subsequently correlating them with germ cell marker expression. A development-specific expression pattern of different keratins as well as vimentin was detected in the prenatal bovine ovary; K18-specific expression was found during all developmental stages (i.e. in surface epithelium, germ cell cord somatic cells, and follicle cells), and keratins $5,7,8,14$, and 19 and vimentin had a stage-specific expression pattern in the different cell populations of the prenatal ovaries. Additionally, our results represent new data on the expression pattern of germ cell markers during bovine ovary prenatal development. S100 alpha and beta protein was localized to oocyte cytoplasm of different follicle stages, and
\end{abstract}

S100 alpha staining could be observed in granulosa cells. Furthermore, through isolation of characteristic ovary cell populations using LAM, specific confirmation of some genes of interest (KRT8, KRT18, S100 alpha, S100 beta, and OCT4, DDX4) could be obtained by RT-PCR in single cell groups of the developing bovine ovary.

(c) 2015 S. Karger AG, Basel

\section{Introduction}

Ovary development is an interesting process and it has been described in many different species [Gondos and Zamboni, 1969; Jost et al., 1973; Byskov, 1980; Motta et al., 1997; Wartenberg et al., 1998; Sawyer et al., 2002; Kenngott et al., 2013]. Morphologically, early gonadal development can be conceived as a longitudinal mesenchymal thickening on the ventromedial side of the mesonephros covered by a mesothelium [Everett, 1943; Witschi, 1948; Rüsse and Sinowatz, 1998; Wrobel and Suss, 1998; Kenngott et al., 2013]. Cellular proliferation within the gonadal anlage is induced by immigrating primordial germ cells (PGC) from the yolk sac [Byskov, 1986; McGee et al., 1998; Rüsse and Sinowatz, 1998; Pereda et al., 2006].

\section{KARGER}

E-Mail karger@karger.com

www.karger.com/cto
(C) 2015 S. Karger AG, Basel

$1422-6405 / 15 / 2002-0153 \$ 39.50 / 0$
Rebecca Anna-Maria Kenngott

Institute for Anatomy, Histology, and Embryology

Department of Veterinary Sciences, Ludwig Maximilian University

Veterinärstrasse 13, DE-80539 Munich (Germany)

E-Mail r.kenngott@anat.vetmed.uni-muenchen.de 


\begin{tabular}{ll}
\hline Abbreviations used in this paper \\
\hline -RT & minus reverse transcriptase \\
ALPI & alkaline phosphatase, intestinal \\
AP & alkaline phosphatase \\
c & cortex \\
CRL & crown-rump length \\
GREL & gonadal ridge epithelial-like \\
IF & intermediate filaments \\
K1 & keratin 1 \\
K5 & keratin 5 \\
K7 & keratin 7 \\
K20 & keratin 20 \\
KRT8/K8 & keratin 8 \\
KRT14/K14 & keratin 14 \\
KRT18/K18 & keratin 18 \\
KRT19/K19 & keratin 19 \\
Ks & keratins \\
LAM & laser-assisted microdissection \\
m & medulla \\
PGC & primordial germ cells \\
SE & surface epithelium \\
Vim & vimentin \\
\hline
\end{tabular}

During the ongoing differentiation in the developing cortex, ovigerous cords and different follicle stages in bovines, as in several other mammalian species, are seen; primordial follicles can prenatally start to grow and differentiate into primary, secondary, and even tertiary follicles. All of these later follicle stages become atretic before birth [Mauleon, 1969; Motta et al., 1997; Rüsse and Sinowatz, 1998; Tanaka et al., 2001; Sawyer et al., 2002; Fortune, 2003; Kenngott et al., 2013].

Numerous marker proteins for tissue organization and differentiation during this differentiation of the ovary have been described in the literature: intermediate filaments (IF) are involved in the loss of a gap junction and indirectly influence the renewal of meiosis. Furthermore, IF, together with microfilaments and microtubules, establish the cytoskeleton [Gall et al., 1992]. Generally, IF can be divided into the following distinct classes: desmin, vimentin, cytokeratins, glial filaments, and neurofilament proteins [Lazarides, 1980; Franke et al., 1982; Gall et al., 1992; reviewed in Steinert et al., 1984]. IF are a part of different cell types. Therefore, each IF group is characteristic of certain tissues: cytokeratins are typical of epithelial cells, vimentin is typical of mesenchymal cells, desmin is typical of a myogenic origin, and glial filaments and neurofilament proteins are typical of different parts of the nervous system [Franke et al., 1979, 1981, 1982; Lazarides, 1980; Moll et al., 1982; Steinert et al., 1984; Lazarides und
Balzer, 1987; Aumuller et al., 1992; Gall et al., 1992; Karlson et al., 2005]. IF probably contribute to different intercellular/nuclear functions and interactions [Lazarides, 1980; Goldmann et al., 1986; Aumuller et al., 1992; Gall et al., 1992]. Moreover, the immunohistochemical expression pattern of the various IF groups is a useful method for comprehension of the biology and neoplastic tissue histology identification [Gabbiani et al., 1981]. Mostly single cell types and their descending neoplasms express or coexpress single or more specific IF [Miettinen et al., 1984; Gould, 1985; McNutt et al., 1985; Viale et al., 1988].

Cytokeratins comprise a prominent class of IF proteins and are divided into 2 classes: class I, i.e. the acid Ks (K9 to K20), and class II, i.e. the basic or neutral Ks (K1 to K8) subfamilies [Franke et al., 1981; reviewed in Moll et al., 1982]. Jackson et al. [1981] demonstrated Ks during embryogenesis. In the fetal and adult ovary, expression of Ks has been described in various manners in structures like surface epithelium cells, the cords, and primordial follicles as well as in the rete ovarii of different species [Czernobilsky et al., 1985; Santini et al., 1993; van den Hurk et al., 1995; Wendl et al., 2012]. Furthermore, Kpositive corpus luteum cells have been detected in bovines [Ricken et al., 1995].

In general, vimentin is a marker for mesenchymal cells [Franke et al., 1978; Karlson et al., 2005] but also for nonmesenchymal cells [Franke et al., 1979]. In the adult ovaries of the rat and the pig, vimentin expression is present in endothelial, granulosa, and stroma cells [Czernobilsky et al., 1985]. van den Hurk et al. [1995] described a positive vimentin reaction in cortical cord epithelium cells and in the granulosa cells of bovine fetal ovaries primary to antral follicles.

During the indifferent bovine ovary development stages, between days 30 and 64 of gestation, development PGC migrate from the yolk, hindgut, and dorsal mesentery into the genital ridge [Rüsse and Sinowatz, 1998]. Many studies have described the expression of pluripotent stem cell markers during early germ cell development to identify the pluripotent nature of these cells: Wrobel and Suss [1998] identified PCG based on the alkaline phosphatase (AP) activity, and Kerr et al. [2008] described, among others, a positive expression pattern for AP, OCT4, and VASA in PGC and oogonia during human ovary development.

S100 expression has been further described in the oocytes of different follicle stages of prenatal ovary phases [Haimoto et al., 1987; Kenngott et al., 2013] or in corresponding granulosa cells [Haimoto et al., 1987; Mirecka et al., 1994]. Kenngott et al. [2013] presumed that an 
S100-positive reaction in oocytes combined with Ki67positive granulosa cells could be a useful marker for intact oocytes in bovine ovaries. Vanstapel et al. [1986] supposed that S100 expression varies with the use of different mono- or polyclonal antibodies.

Laser-assisted microdissection (LAM) has been used in numerous studies to isolate specific cell populations without contaminating the surrounding cells [Gjerdrum and Hamilton-Dutoit, 2005; Murray, 2007; Kenngott et al., 2011]. Murray [2007] described an effective method to obtain tissue cells using LAM. The procedure of isolation of total RNA from paraffin-embedded formalin-fixed tissue has been described in earlier studies [Abrahamsen et al., 2003; Lehmann and Kreipe, 2006; Kenngott et al., 2011].

In a prior study, Kenngott et al. [2013] described important steps of the developing prenatal ovary as well as morphological criteria for the different cell populations in the bovine prenatal ovary. The aim of our present study is to investigate more closely the expression pattern of IF [cytokeratins (keratins; Ks): K5, K7, K8, K14, K18, K19, and vimentin] in different compartments of the fetal bovine ovary ( surface epithelium, germ cell cords, follicular cells, and stromal cells of the cortex and medulla) using immunohistochemical techniques. Germ cell differentiation was analyzed using antibodies against potential germ cell markers [alkaline phosphatase, intestinal (ALPI), OCT4, DDX4 (VASA), S100 alpha, and S100 beta]. Additionally, the expression of the corresponding mRNA was evaluated in specific cell groups, which were microdissected from the fetal bovine ovary and detected by RTPCR.

\section{Materials and Methods}

\section{Tissue Samples and Preparation}

The procedure for fetus collection, cutting, fixation, and preparation was as described in our previous papers [Kenngott et al., 2010, 2013], with modification of the methods described by $\mathrm{Mu}-$ lisch and Welsch [2010]: 'in brief, ovaries from bovine fetuses of different developmental stages [crown-rump length (CRL) range $11.0-94.0 \mathrm{~cm}$ ] were removed and cleaned of surrounding tissues within $10 \mathrm{~min}$ after slaughter. Fetuses with a CRL below $2.5 \mathrm{~cm}$ were fixed in toto in Bouin's solution [Mulisch and Welsch, 2010] or 3.7\% phosphate-buffered formalin [Mulisch and Welsch, 2010] for $12 \mathrm{~h}$. Fetuses exceeding this length were cut at the level of the cuboidal joint as described in a previous study [Kenngott et al., 2013]. The liver, intestines, and limbs were removed from the caudal half of the fetus. The remaining specimens were fixed in Bouin's fluid or $3.7 \%$ formalin for up to $48 \mathrm{~h}$. Fetuses with a CRL of more than $10.0 \mathrm{~cm}$ had their ovaries dissected additionally and fixed again like the tissue above for the same period of time as described in the studies of Kenngott and Sinowatz [2007, 2008] and Kenngott et al. [2013]. After fixation, each sample was dehydrated (graded series of alcohols) and then embedded in paraffin. Serial sections $(5 \mu \mathrm{m})$ were cut using a Leitz microtome (Typ1516; Leitz GmbH, Wetzlar, Germany). The fetuses and ovaries used in this investigation showed no anomalies morphologically. Using tables from the study of Rüsse and Sinowatz [1998], gestational age was calculated based on the measured CRL of the fetuses.'

\section{Immunohistochemistry}

Immunohistochemistry was performed according to protocols (modified for the antibodies used and according to the methods of Mulisch and Welsch [2010]) and Noll and Schaub-Kuhnen [2000], and these were previously used and described in studies of the prenatal bovine genital tract [Kenngott and Sinowatz, 2007, 2008; Kenngott et al., 2013]. Additionally, mostly the same tissue blocks as in an earlier study [Kenngott et al., 2013] were used. 'Briefly, serial 5- $\mu \mathrm{m}$ sections were mounted on APES (aminopropyltriethoxysilane)-coated slides (SupraFrost Ultra Plus; Menzel-Gläser, Braunschweig, Germany). The slides were dried overnight at $37^{\circ} \mathrm{C}$, dewaxed, and rehydrated in a series of alcohols of decreasing concentrations. After incubation with proteinase XXIV $0.1 \%$ (P8038; Sigma) for $15 \mathrm{~min}$, the sections were washed with PBS buffer, $\mathrm{pH}$ 7.4. Additionally, endogenous peroxidase activity was blocked with $0.1 \% \mathrm{H}_{2} \mathrm{O}_{2}$ at room temperature for $10 \mathrm{~min}$. Dako Protein Block Serum-Free was applied for 20 min to reduce nonspecific antibody binding, and sections were then rinsed in PBS (3 $\times 5 \mathrm{~min}$ ). As described by Noll and Schaub-Kuhnen [2000], incubation was processed in humid chambers at a temperature of $4^{\circ} \mathrm{C}$ using the $\mathrm{ABC}$ technique. The polyclonal and monoclonal antibodies used as primary antibodies are listed in table 1. After incubation with the secondary antibody, the slides were washed with PBS $(3 \times 5 \mathrm{~min})$ followed by a visualization procedure using DAB (diaminobenzidine) for 5-10 min. To stop the reaction, sections were then thoroughly washed in distilled water. Then, the slides were slightly counter-stained with hematoxylin (30 s).

For negative controls, the specific primary antibody was replaced by buffer (Dako, Hamburg, Germany). Positive controls were prepared on tissues with known specific immunostaining for the respective antibodies used in this study.'

\section{Preparation of Tissue for LAM}

LAM preparation and procedure were done employing the technique also described by Kenngott et al. [2010, 2011], and as described by the information of Zeiss (Munich, Germany), performed in relation to the prenatal ovary tissue. A PALM MicroBeam laser system (Zeiss, Munich, Germany) was used, consisting of an inverted microscope (Zeiss Axio Observer) equipped with $\times 5, \times 10, \times 20, \times 40$, and $\times 63$ objectives and operated with a motorized stage and a 'cold' solid-state UVA laser. For the preliminary histological evaluation, tissue sections (10, 20, 30, and $40 \mu \mathrm{m})$ were stained with hematoxylin (Mayer's hematoxylin; Sigma). Ovary sections of $40 \mu \mathrm{m}$ could be clearly evaluated using all objectives (fig. 1).

\section{LAM Procedure}

The LAM procedure is shown in figure $1 \mathrm{a}-\mathrm{h}$. In this study, microdissection was carried out using $\times 10$ or $\times 20$ objectives. Regions of interest of fetuses (with CRL of 29.2, 44.8, and $90.0 \mathrm{~cm}$ ) were then located and manually outlined on a visual display unit. Using the provided software, the microscope was directed to the specified ar- 

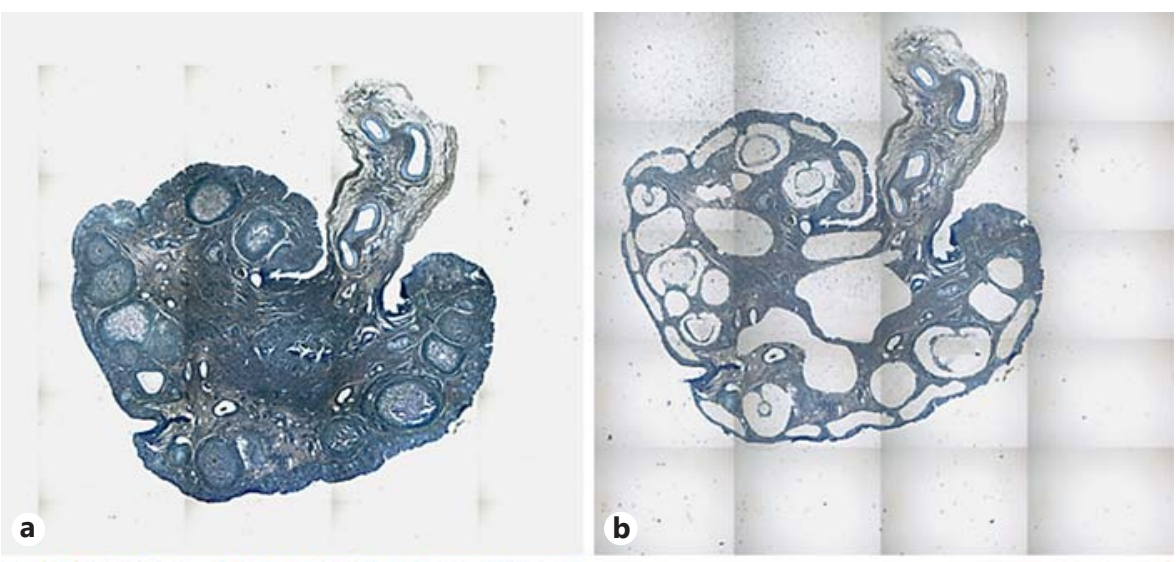

Fig. 1. a-h LAM procedure. Example: bovine prenatal ovary. a Fetal ovary with a CRL of $90.0 \mathrm{~cm}$ stained with hematoxylin. In the cortex, different follicle stages can be observed. Further, note the rete ovarii in the medulla. $\mathbf{b}$ The same section of the prenatal ovary after LAM. c-f The surface epithelium (yellow), oocytes (flags), granulosa cells, and stroma (red), as well as the rete ovarii (purple), are marked with a single color for each cell population. Green: germ cell cords. Scale bars $=300 \mu \mathrm{m}$. d Yellow: laser points, follicle cells. Blue: oocyte. f Yellow: laser points. Blue: oocyte. g The specific cell groups were cut with a finetuned laser and catapulted into the caps of different tubes. $\mathbf{h}$ Overview of the ovary on coated slides before LAM.
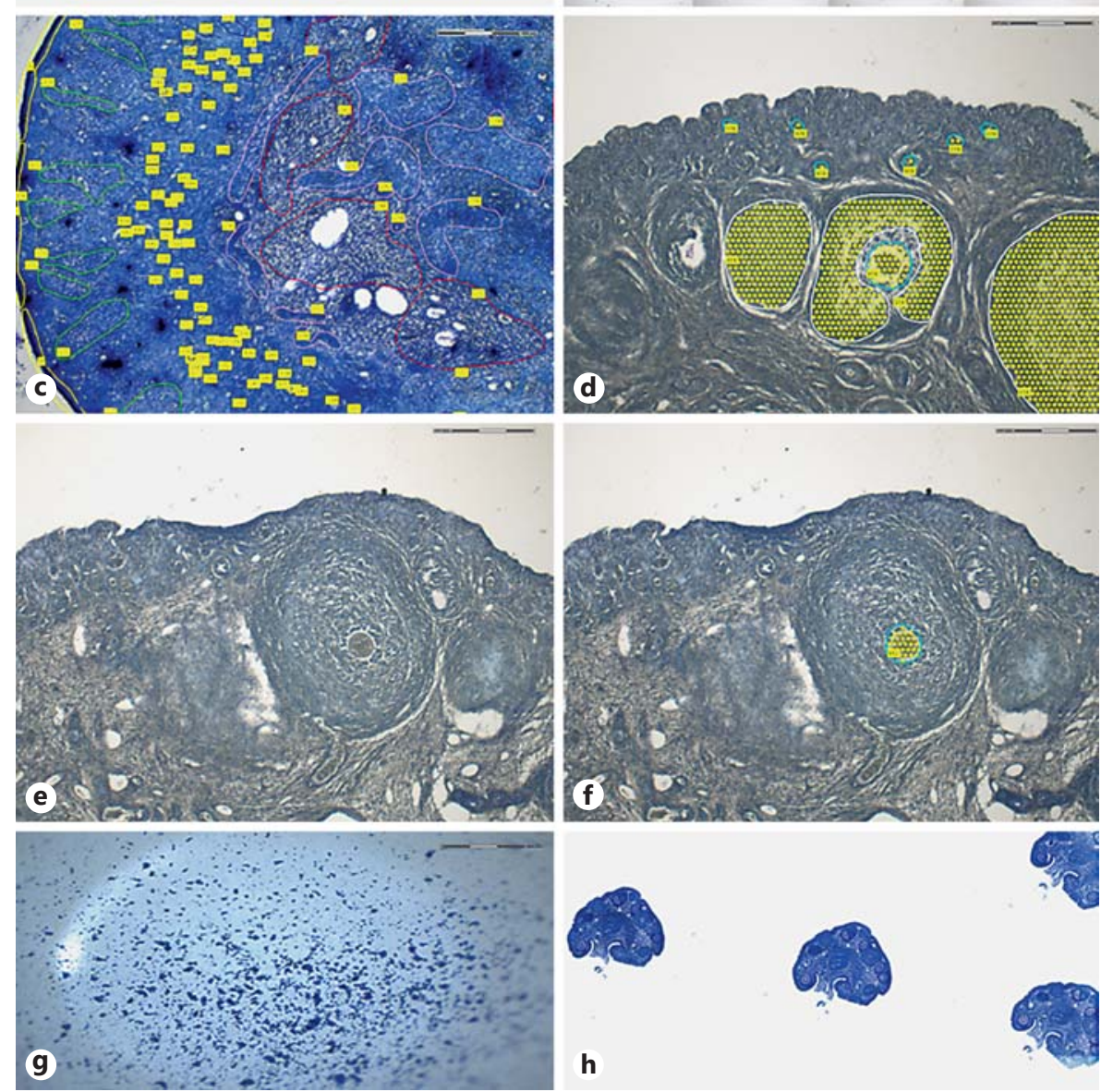

g
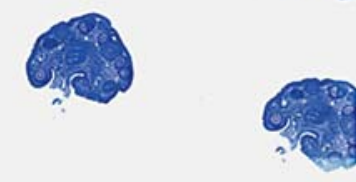

eas to collect the previously delineated regions. A fine-tuned 355$\mathrm{nm}$ pulsed UVA laser cut the cells of interest out of the surrounding tissue. The isolated cells were retrieved using a noncontact collection method, ejecting cells of each area into a separate overlying receptacle (cap of a 0.5-ml Eppendorf tube with a depressed lid, PALM MicroBeam; Zeiss). The cell number of each tissue compartment of the fetal ovaries (surface epithelium, germ cell cords, stroma of the medulla, rete ovarii, oocytes, and granulosa cells) was equalized by harvesting an area of $\sim 10^{6} \mu \mathrm{m}^{2}$ in each respective cap. A Zeiss AxioCam 1Cc1 was used to document the areas of the retrieved speci- mens of the sections before and after cell capture. The corresponding captured cells attached to the lids were also photographed.

\section{RNA Extraction and cDNA Synthesis}

Total RNA was isolated from microdissected FFPE tissue using an RNeasy FFPE Kit (Qiagen, Hilden, Germany). Initially, proteinase $\mathrm{K}$ was added to the tubes and incubation was performed for $24 \mathrm{~h}$. The optimal RNA extraction procedure for FFPE microdissected tissue is described in the study of Kenngott et al. [2011], and a short procedure is described in Kenngott et al. [2010]. 
Table 1. Overview of the antibodies used

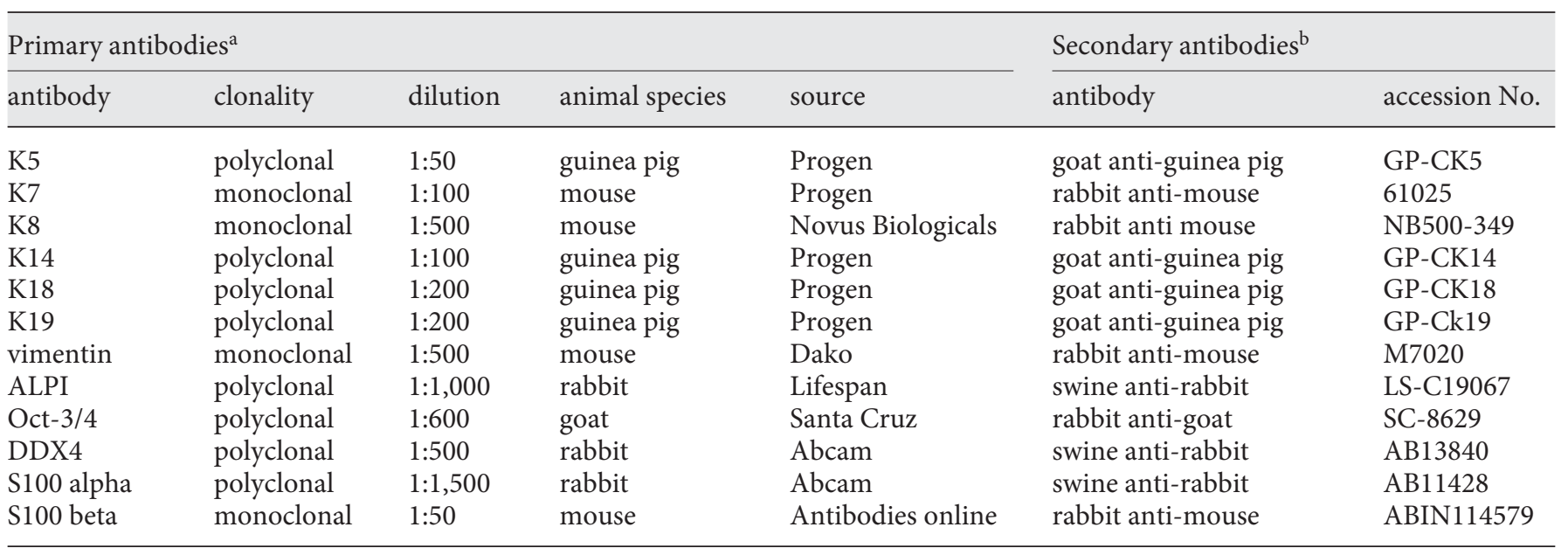

a The incubation time and incubation temperature were $20 \mathrm{~h}$ and $4^{\circ} \mathrm{C}$, respectively, for all antibodies. ${ }^{\mathrm{b}}$ The dilution, incubation time, and incubation temperature were 1:300, $30 \mathrm{~min}$, and room temperature, respectively, for all antibodies.

Table 2. Overview of the primer pairs used

\begin{tabular}{|c|c|c|c|c|}
\hline Primer & Forward primer & Reverse primer & $\begin{array}{l}\text { Nucleotide product } \\
\text { size, bp }\end{array}$ & $\begin{array}{l}\text { GenBank } \\
\text { accession No. }\end{array}$ \\
\hline $\mathrm{KRT}^{\mathrm{a}}$ & $5^{\prime}$ ggc aac atg cag ggg ctg gt $3^{\prime}$ & $5^{\prime}$ cca ggc ggg act cca gct ct $3^{\prime}$ & 148 & NM_001033610.1 \\
\hline KRT14 & $5^{\prime}$ agc ggc ctg ctg aga tca agg ac $3^{\prime}$ & $5^{\prime}$ cag cag cca gac ggg cat tgt $c 3^{\prime}$ & 132 & NM_001166575.1 \\
\hline $\mathrm{KRT}_{1}{ }^{\mathrm{a}}$ & $5^{\prime}$ tca tcg agg acc tga ggg ctc aga $3^{\prime}$ & $5^{\prime}$ gcg cat ggc cag ctc tgt ctc $3^{\prime}$ & 131 & NM_001192095.1 \\
\hline KRT19 & $5^{\prime}$ tac cag aag cag ggg ccc gg $3^{\prime}$ & $5^{\prime} \mathrm{ctt}$ gga gtt ctc aat ggt ggc acc g3' & 105 & NM_001015600.2 \\
\hline vimentin $^{\mathrm{a}}$ & $5^{\prime}$ aag ccg aga gca ctc tgc agt ct3' & $5^{\prime}$ ggg cct gaa gct cct gga ttt cct $3^{\prime}$ & 150 & NM_173969.3 \\
\hline S100 alpha (S100A1) & $5^{\prime}$ agg agc tga aag agc tgc tg $3^{\prime}$ & $5^{\prime}$ tcc acc tct cca tct ccg tt $3^{\prime}$ & 118 & NM_001099042.2 \\
\hline S100 beta (S100B) & $5^{\prime}$ agg tga caa gca caa gct g3' & $5^{\prime}$ tgg aag tca cat tcg ccg tc $3^{\prime}$ & 150 & NM_001034555.3 \\
\hline DDX4 & $5^{\prime}$ ggc ttc atc gtc aga aat ggg $3^{\prime}$ & $5^{\prime} \mathrm{cca}$ act cca aaa cca ccc ac3' & 150 & NM_001007819.1 \\
\hline OCT4 (POU5F1) & $5^{\prime}$ cga agc tgg aca agg aga ag $3^{\prime}$ & $5^{\prime} \operatorname{tgc} \mathrm{ttt}$ agg agc ttg gca aat $3^{\prime}$ & 100 & NM_174580.2 \\
\hline
\end{tabular}

a According to Wendl et al. [2012].

cDNA synthesis of the extracted total RNA elutes was carried out using a SuperScript cDNA Synthesis Kit (BioRad, Munich, Germany) according to the manufacturer's instructions. The absence of genomic DNA in each RNA sample was confirmed by a minus reverse transcriptase $(-\mathrm{RT})$ control. The $-\mathrm{RT}$ control is a mock reverse transcription containing all of the RT-PCR reagents, with the exception of reverse transcriptase. The presence of an amplification product in the -RT control is therefore indicative of contamination of the DNA in the sample. The cDNA synthesis was in line with the procedure of earlier investigations [Kenngott et al., 2011].

\section{Primer Design}

The primer design was carried out according to Kenngott et al. [2011] and Wendl et al. [2012]. mRNA sequences were retrieved from the National Center for Biotechnology Information (http:// www.ncbi.nlm.nih.gov/pubmed/ - nucleotide) for the following genes: K8, K14, K18, K19, vimentin, OCT4, DDX4, S100 alpha, and S100 beta (listed in table 2).

Primer pairs were designed using the 'pick primers' option of the respective mRNA display (http://www.ncbi.nlm.nih.gov/nuccore) in order to simultaneously show the exon constellation of forward and reverse primers.

Primer pairs were chosen to generate RT-PCR products between 100 and $170 \mathrm{bp}$, as the RNA recovered from FFPE lasermicrodissected material was expected to be considerably fragmented. The bovine sequences used for the primer design are shown in table 2 ( $18 \mathrm{~S}$ was used only as an internal system control). All primer pairs were designed in an intron-flanking fashion, with the intron forced to be larger than 1,000 bp, thus excluding the possibility of amplification of genomic DNA through our RT-PCR protocol. The primers were synthesized by MWG-Biotech (Ebers- 
Table 3. Overview of the staining patterns of Ks and vimentin in the developing prenatal ovary

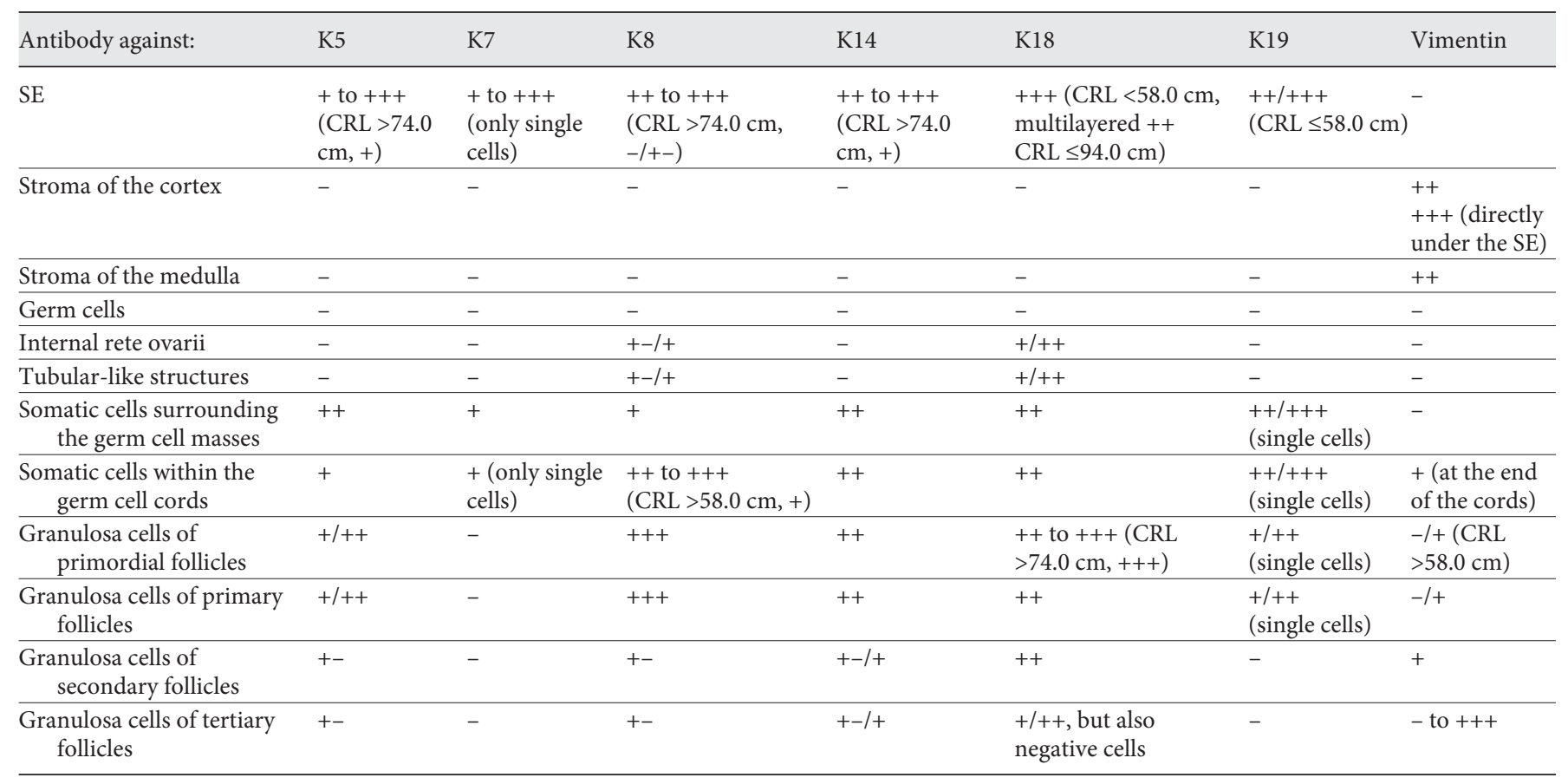

SE = Surface epithelium; - = negative; +- = sporadically positive; + = weakly positive; ++ = distinctly positive; $+++=$ strongly positive.

berg, Germany). The concentration of the primer sets was matched to $1.2 \mathrm{pmol} / \mu \mathrm{l}$. To guarantee the specificity of each primer pair, the amplicons (produced by known positive tissue) were additionally sequenced by GENterprise (GENterprise GENOMICS, Mainz, Germany) and evaluated using a tool named FINCH, again linked to a BLAST search (www.ncbi.nlm.nih.gov/BLAST).

\section{$R T-P C R$}

Using specific primer pairs (table 2), sequences of the genes of interest were amplified by RT-PCR. The RNA quality of the isolated RNA was evaluated using the microfluid-based automated electrophoresis system Experion (BioRad). The exact procedure is described in the study of Kenngott et al. [2011]. Reaction volumes for a total of $15 \mu \mathrm{l} /$ well were set up, containing $7.5 \mu \mathrm{l}$ of EVAGreen master mix (BioRad), $3 \mu \mathrm{l}$ of cDNA template, and $4.5 \mu$ of primer pairs ( $0.4 \mathrm{~mm}$ primer, reverse and forward). Nontemplate controls were prepared with each primer pair by substituting the cDNA in the above setup with aqua distillate.

For the RT-PCR reaction, a CFY 96 cycler (BioRad) was used with the following 2-step temperature protocol: phase $1: 95^{\circ} \mathrm{C}$ for 3 min for enzyme activation, and phase 2 : 50 cycles at $95^{\circ} \mathrm{C}$ for $15 \mathrm{~s}$ (denaturizing) and $60^{\circ} \mathrm{C}$ for $10 \mathrm{~s}$ (annealing and extension).

The RT-PCR products were run on a $1.5 \%$ Gel-Red (VWR)stained agarose gel. The band results were compared to a DNA Sizer XII marker (Peqlab, Erlangen, Germany).

Definitions and important time points were used to identify the structures in the prenatal ovary. Similar observations were described, among others, in sheep by Sawyer et al. [2002] and in bovines by Burkhart et al. [2010] and van den Hurk et al. [1995]. Ad- ditionally, the following development observations and important time points were described in the earlier studies of Kenngott et al. [2013] during the development of bovines:

- Germ cell nests/groups: 'Groups of oogonia lying directly under the incomplete basal lamina of the multilayered surface epithelium. They are surrounded and intermingled by mostly longitudinally elongated and thin somatic cells. The germ cell nests are separated by stromal tissue.'

- Germ cell cords: 'The first step in the development of the germ cell cords is elongation of germ cell nests/groups. The basal lamina of the surface epithelium is in continuous connection with the basal lamina of the germ cell cords. On the end of the cords primordial follicles are separated which were enclosed by a basal lamina.'

- Tubular-like structures: 'Tubular-like structures are located in the medulla or on the end of the germ cell cords and enclose an irregularly single to multilayered epithelium. The epithelium cells sit on a continuous basal lamina.'

- In line with Mosimann and Kohler [1990], atretic follicles are characterized by shrunken oocytes and disaggregation of the granulosa cell layers.

\section{Results}

The expression pattern of the different antibodies is summarized in table 3 . The negative controls produced no immunostaining. The positive tissue controls showed 
distinct immunostaining of the expected cells and tissues. An overview of the Ks and the vimentin staining pattern in the developing prenatal ovary are shown in table 3.

\section{Expression of Cytokeratins (K5, K7, K8, K14, K18,} and K19)

The surface epithelium of the developing fetal bovine ovary expressed K5 from a CRL of 7.4-74.0 cm (fig. 2a). The staining intensity of the ovarian surface epithelium for CRL of 34.0-74.0 cm was stronger compared to the earlier stages. A distinct expression of $\mathrm{K} 5$ was found in multilayered epithelial areas (fig. 2d), whereas K5-negative cells occurred in epithelial areas, which consisted of only few cell layers (fig. 2a). During later stages of development (from a CRL of $74.0 \mathrm{~cm}$ onwards), only weak staining for K5 was found in surface epithelium cells (fig. 2e). Ovarian medulla polygonal stroma cells were completely negative for $\mathrm{K} 5$ at all investigated stages. Likewise, round-to-oval PGC, i.e. oogonia and oocytes, showed no reaction to K5. From $7.4 \mathrm{~cm}$ onwards, PGC and oogonia were arranged in nests [Kenngott et al. 2013], surrounded by or intermingled with K5-positive, elongated, thin cells. K5 protein-positive cells could be observed within the germ cell cords. The expression intensity of K5 protein-positive cells in the surface epithelium as well as in the elongated, thin cells near the germ cell nests significantly exceeded the staining intensity of K5positive cells within the germ cell cords. From a CRL of $15.8 \mathrm{~cm}$ onwards, oocyte-pregranulosa groups budded off from the free ends of the germ cell cords [Kenngott et al., 2013]. The granulosa cells of these groups showed expression of the K5 protein in their cytoplasm (fig. 2b). The follicle cells of primordial and primary follicles mostly expressed K5 sporadically and with different cytoplasmstaining intensities (fig. 2c). K5 immunostaining was weaker in secondary- and tertiary-follicle granulosa cells. In the rete ovarii epithelium or rete-associated tubular structures, no expression of K5 could be observed.

The K7 expression pattern was confined to only few cells of the surface epithelium up to $74.0 \mathrm{~cm}$, which showed varying staining intensities ranging from weak to strong positive immunostaining. Furthermore, only few cells lying within the germ cell nests, directly under the surface epithelium or in the germ cell cords, expressed K7 up to a CRL of $58.0 \mathrm{~cm}$ (fig. 2f).

K8 expression was strongly positive in the surface epithelium cytoplasm of all investigated stages up to a CRL of $74.0 \mathrm{~cm}$ (fig. $2 \mathrm{~g}$, h). For CRL of 74.0-94.0 cm, it showed merely weak (only in single cells) or negative staining for
K8. Furthermore, germ cell nest and germ cell cord pregranulosa cells expressed K8 intensively up to at CRL of $58.0 \mathrm{~cm}$, with a significantly decreasing staining intensity during later developmental stages. Strong immunostaining for K8 was detected in primordial- and primary-follicle cells at all investigated stages (fig. $2 \mathrm{i}, \mathrm{j}$ ), whereas K8 expression diminished in later-follicle-stage granulosa cells. Cortex and medulla spinocellular stromal cells were negative for K8.

The expression pattern of K14 in the surface epithelium and germ cell nest and cords was very similar to that of $\mathrm{K} 5$, but the staining intensity was generally more intense compared to K5 immunostaining. K14 expression could be observed in follicle cells with different intensities. No staining for K14 could be observed in the rete ovarii, and none was seen in tubular-like structures.

A special expression pattern was found using an antibody against K18. The cytoplasm of the multilayered elongated surface epithelium cells was mostly strongly positive (fig. $2 \mathrm{k}, \mathrm{l}$ ). In the monolayered epithelium, K18positive and K18-negative epithelium cells could be observed. Shaped like the K18-positive surface, epithelium cells were interspersed between the negative cells in the germ cell nests. Furthermore, small elongated K18-positive somatic cells built the outer layer of the germ cell cord wall lying longitudinally directly beneath the basal lamina [Kenngott et al., 2013] (fig. 2m, n). By the time the pregranulosa oocyte aggregates detach from the germ cell cord blind end [Kenngott et al., 2013], primordialand primary-follicle cells show a distinct to strong expression of K18. Even in later developmental stages, now with existing follicles of all stages (primordial, primary, secondary, and tertiary follicles exist), multilayered granulosa cells as well as the somatic cells of the remaining germ cell cords expressed K18 (fig. 2o, p). Additionally, granulosa cells of all follicle stages were distinctly immunostained for K18 (fig. 2q, r). In multilayered follicles, the K18 expression was strongest in basal and follicular lying follicle cells. No positive immunostaining for K18 protein was found in tertiary-follicle theca interna and externa. Rete ovarii epithelial cells consistently expressed K18.

Ovarian surface epithelium expressed K19 distinctly, staining the whole cytoplasm (fig. 2s) up to a CRL of 58.0 $\mathrm{cm}$. The germ cell cord somatic cells also showed distinct K19 expression, whereas the germ cells were always negative (fig. 2s). Granulosa cells were characterized by a different expression intensity in primordial and primary follicles with punctual K19 staining (fig. 2t) in some granulosa cells. Many unstained follicular cells could also be 

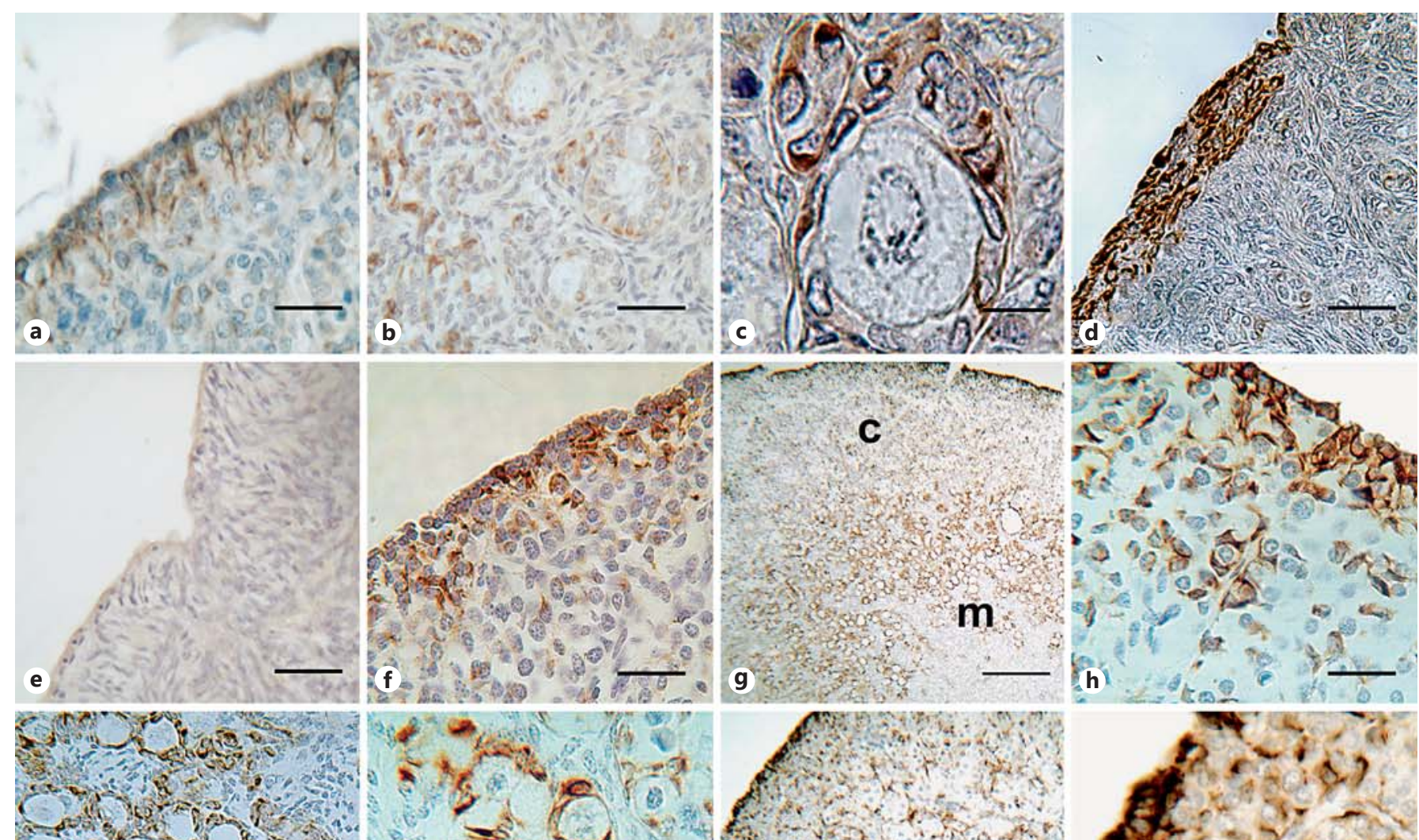

(3)

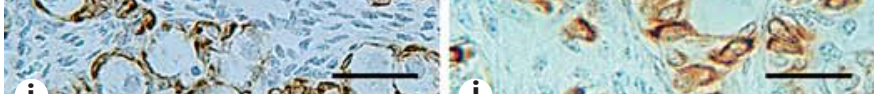
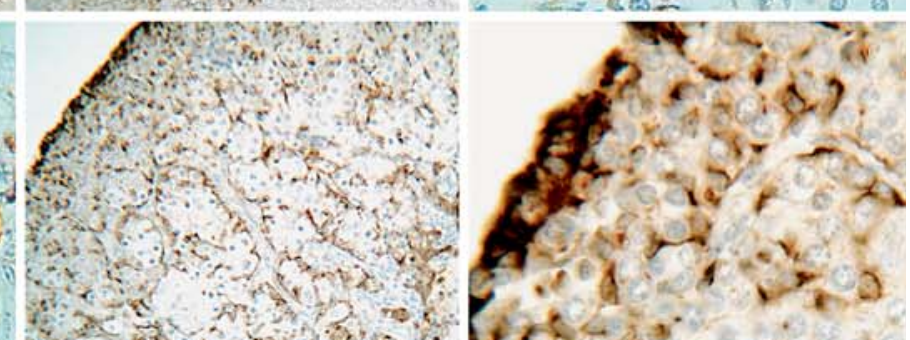

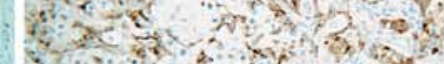

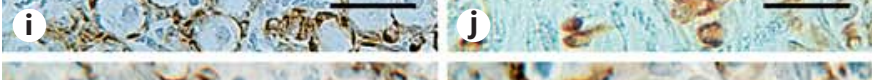

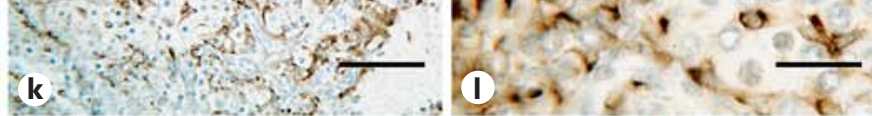

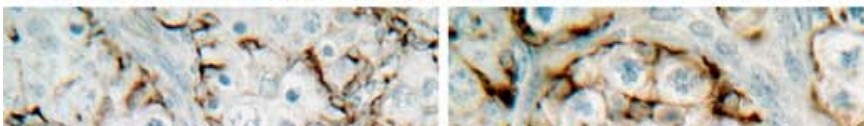

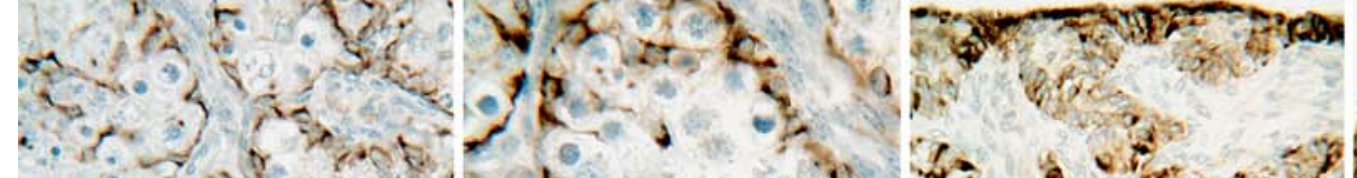

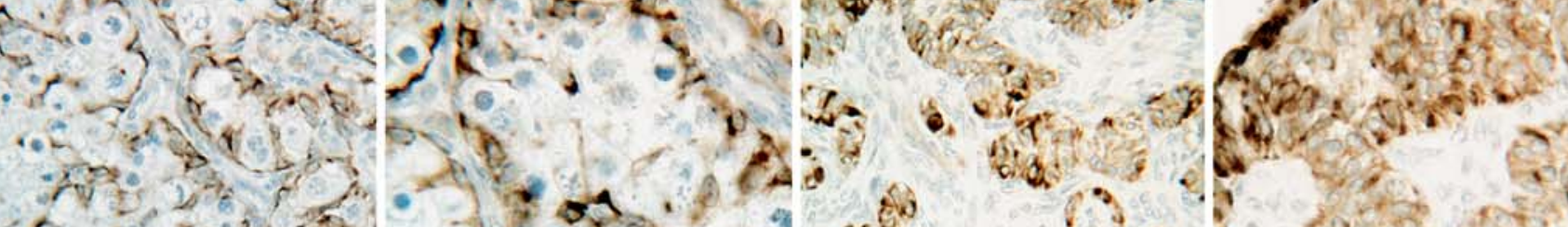

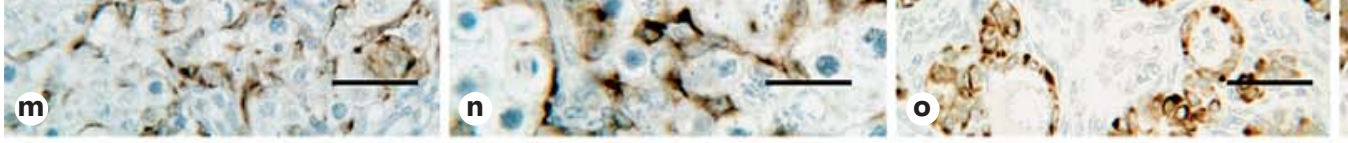

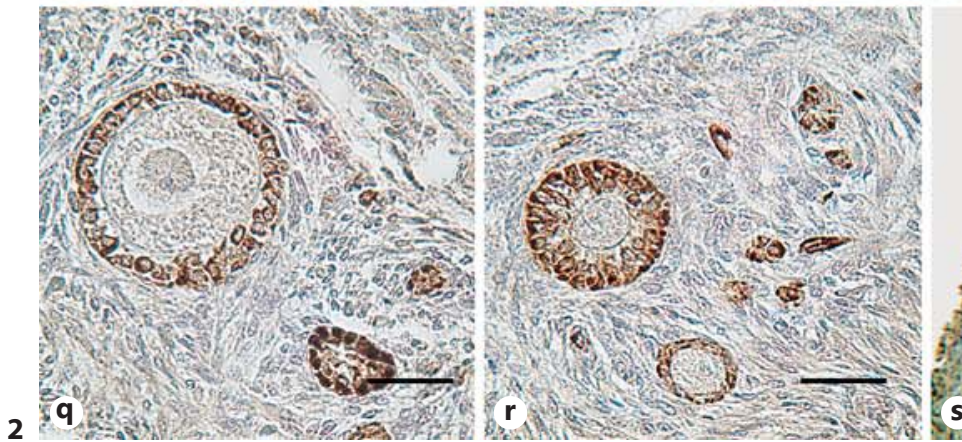

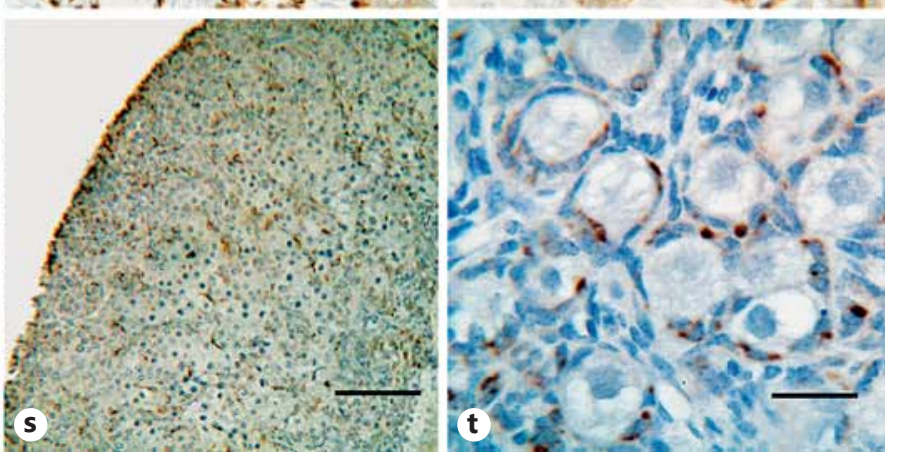

(For legend see next page.) 
observed. No K19 staining was detected in more advanced follicular stages. The rete ovarii remained unstained at all ovary development stages.

\section{Expression Pattern of Vimentin}

The surface epithelium as well the as pregranulosa cells in the germ cell nests and germ cell cords did not show any immunostaining for vimentin. The germ cells in the germ cell nest were negative for the antibody against vimentin. Vimentin staining was found in the cortex stromal cell cytoplasm. The staining appeared to be more intense in the cytoplasm of stromal cells, which were located immediately beneath the surface epithelium or between the germ cell cords (compared to other areas of the cortex). A strong expression of vimentin was found in

Fig. 2. a-t Immunohistochemically stained serial sections of various prenatal ovaries showing an overview of different $\mathrm{K}$ expression patterns in prenatal bovine ovaries during different developmental stages. The cortex (c) and medulla ( $\mathrm{m}$ ) are labeled for orientation. a Section of the ovary of a fetus with a CRL of $44.8 \mathrm{~cm}$. Note the K5-positive expression in cells of the single-layered surface epithelium intermingled with K5-negative epithelium cells. Scale bar = $50 \mu \mathrm{m}$. Antibody against the K5 protein. $\mathbf{b}$ Section of the ovary of a fetus with a CRL of $44.8 \mathrm{~cm}$. At the end of the germ cell cords, granulosa cells of primordial and primary follicles show K5-positive staining in the cytoplasm. The stroma between the follicles is $\mathrm{K} 5$ negative. Scale bar $=50 \mu \mathrm{m}$. Antibody against the $\mathrm{K} 5$ protein. c Section of the ovary cortex of a fetus with a CRL of $44.8 \mathrm{~cm}$. In the follicle cell cytoplasm, diffuse K5 staining can be observed. In contrast, no staining for the antibody against $\mathrm{K} 5$ is detected in the oocyte. Scale bar $=20 \mu \mathrm{m}$. Antibody against the K5 protein. $\mathbf{d}$ Section of the ovary surface epithelium and cortex of a fetus with a CRL of $57.6 \mathrm{~cm}$. Note the intensive expression of K5 in the cytoplasm of multilayered surface epithelium cells. Scale bar $=50 \mu \mathrm{m}$. Antibody against the K5 protein. e Section of the ovary surface epithelium and cortex of a fetus with a CRL of $90.0 \mathrm{~cm}$. No or only a weak reaction for the antibody against the $\mathrm{K} 5$ protein could be detected in the surface epithelium of an ovary with a CRL of 90.0 $\mathrm{cm}$. Scale bar $=50 \mu \mathrm{m}$. Antibody against the K5 protein. $f$ Section of the ovary surface epithelium and cortex of a fetus with a CRL of $21.0 \mathrm{~cm}$. Surface epithelium cells as well as somatic cells of the germ cell cords show expression of K7 with a varying staining intensity. Scale bar $=50 \mu \mathrm{m}$. Antibody against the K7 protein. $\mathbf{g}$ Section of the ovary surface epithelium, cortex, and medulla of a fetus with a CRL of $21.0 \mathrm{~cm}$. In the surface epithelium, the somatic cells of the germ cell cords, and the follicle cells of the detaching primordial follicles, intensive staining for K8 is present. Scale bar $=100 \mu \mathrm{m}$. Antibody against the K8 protein. $\mathbf{h}$ Section of the ovary surface epithelium of a fetus with a CRL of $21.0 \mathrm{~cm}$. The surface epithelium cells and somatic cells of the ongoing germ cell cords show strong cytoplasm staining for K8. Scale bar $=50 \mu \mathrm{m}$. Antibody against the K8 protein. $\mathbf{i}, \mathbf{j}$ Section of the ovary cortex near the medulla of a fetus with CRL of 21.0 and $29.8 \mathrm{~cm}$. Intensive cytoplasm staining the fetal ovary tunica albuginea from a CRL of $90.0 \mathrm{~cm}$ onwards. Single punctual vimentin expression was seen in the follicle cell cytoplasm on the end of the cords where the primordial follicles broke down [Kenngott et al., 2013]. Vimentin-positive staining could be observed in later stages (from $58.0 \mathrm{~cm}$ onwards) within the multilayered granulosa cell layer. Especially the basally located granulosa cell cytoplasm (weak expression) and the inner layer of the follicular cells (of early tertiary and antral follicles as well as corona radiata cells) were distinctly stained by the vimentin antibody. The remaining granulosa cells showed a weaker/negative selective vimentin expression in their cytoplasm. Additionally, no vimentin-positive staining could be observed either in theca cells or in the oocyte cytoplasm of any follicle stage.

for K8 was detected in the follicular cells of primordial as well as primary follicles. Scale bars $=50 \mu \mathrm{m}$. Antibody against the K8 protein. $\mathbf{k}$, I Characteristic expression pattern for the antibody against K18 seen in all investigated developmental stages. $\mathbf{k}$ Section of the whole ovary cortex and partially of the medulla of a fetus with a CRL of $15.8 \mathrm{~cm}$. Intensive staining of the surface epithelium cells and the somatic cells of the germ cell cords is visible. The oogonia and oocytes (at the end of the germ cell cords) show no reaction to the antibody against K18. Scale bar $=80 \mu \mathrm{m}$. Antibody against the K18 protein. I Section of the surface epithelium and cortex of a fetus with a CRL of $15.8 \mathrm{~cm}$. The multilayered surface epithelium shows a strong positive reaction to the K18 protein in the cytoplasm. Scale bar $=50 \mu \mathrm{m}$. Antibody against the K18 protein. $\mathbf{m}, \mathbf{n}$ Section of the germ cell cords in the cortex of a fetus with a CRL of $15.8 \mathrm{~cm}$. K18-positive somatic cells build the wall of the germ cell cords. Note the K18-negative germ cells as well as the negative stroma outside the germ cell cords. Also, the germ cells within the cords were completely negative for the antibody against K18. Scale bars $=50 \mu \mathrm{m}(\mathbf{m})$ and $20 \mu \mathrm{m}(\mathbf{n})$. Antibody against the K18 protein. $\mathbf{0}, \mathbf{p}$ Section of the germ cell cords in the cortex of a fetus with a CRL of $57.6 \mathrm{~cm}$. The cytoplasm of surface epithelium cells, the somatic cells of the germ cords, and the granulosa cells of detaching follicles were always strongly positive for the antibody against K18. The stroma between the germ cell cords and the follicles was negative for the antibody against K18. Scale bars $=50 \mu \mathrm{m}$. Antibody against the K18 protein. $\mathbf{q}$, $\mathbf{r}$ Section of the cortex of a fetus with a CRL of $90.0 \mathrm{~cm}$. In prenatal ovaries from later developmental stages, the cytoplasm of the follicles presented an ongoing strong expression of K18 in the cytoplasm. Note the strong K18 expression of the secondary follicle cells for a CRL of $90.0 \mathrm{~cm}$. The developing theca cells were negative for the antibody against K18. Scale bars = $50 \mu \mathrm{m}$. Antibody against the K18 protein. s Section of the cortex of a fetus with a CRL $15.8 \mathrm{~cm}$. K19 expression can be observed in the surface epithelium cells as well as in somatic cells of the germ cell cords. Scale bar $=100 \mu \mathrm{m}$. Antibody against K19. $\mathbf{t}$ Section of the cortex of a fetus with a CRL of $21.0 \mathrm{~cm}$. Selective staining for K19 in the cytoplasm of primordial and primary follicles. Scale bar $=50$ $\mu \mathrm{m}$. Antibody against K19. 
Expression Pattern of ALPI, OCT4, and DDX4

In this study, we used an antibody against calf intestinal AP (ALPI; compare used antibody). The positive tissue control (bovine intestine) showed distinct immunostaining of the expected cells and tissue areas.

The expression pattern of ALPI was concentrated in early germ cells. The strongest staining intensity was seen in the polygonal to round PGC predominantly located in the surface epithelium (up to a CRL of $58.0 \mathrm{~cm}$ ). A weaker ALPI reaction was seen in single, more voluminous, round oogonia of germ cell nests from earlier ovary stages (fig. 3a). Oocytes showed no ALPI expression during the later developmental phases (from a CRL of $15.8 \mathrm{~cm}$ onwards).
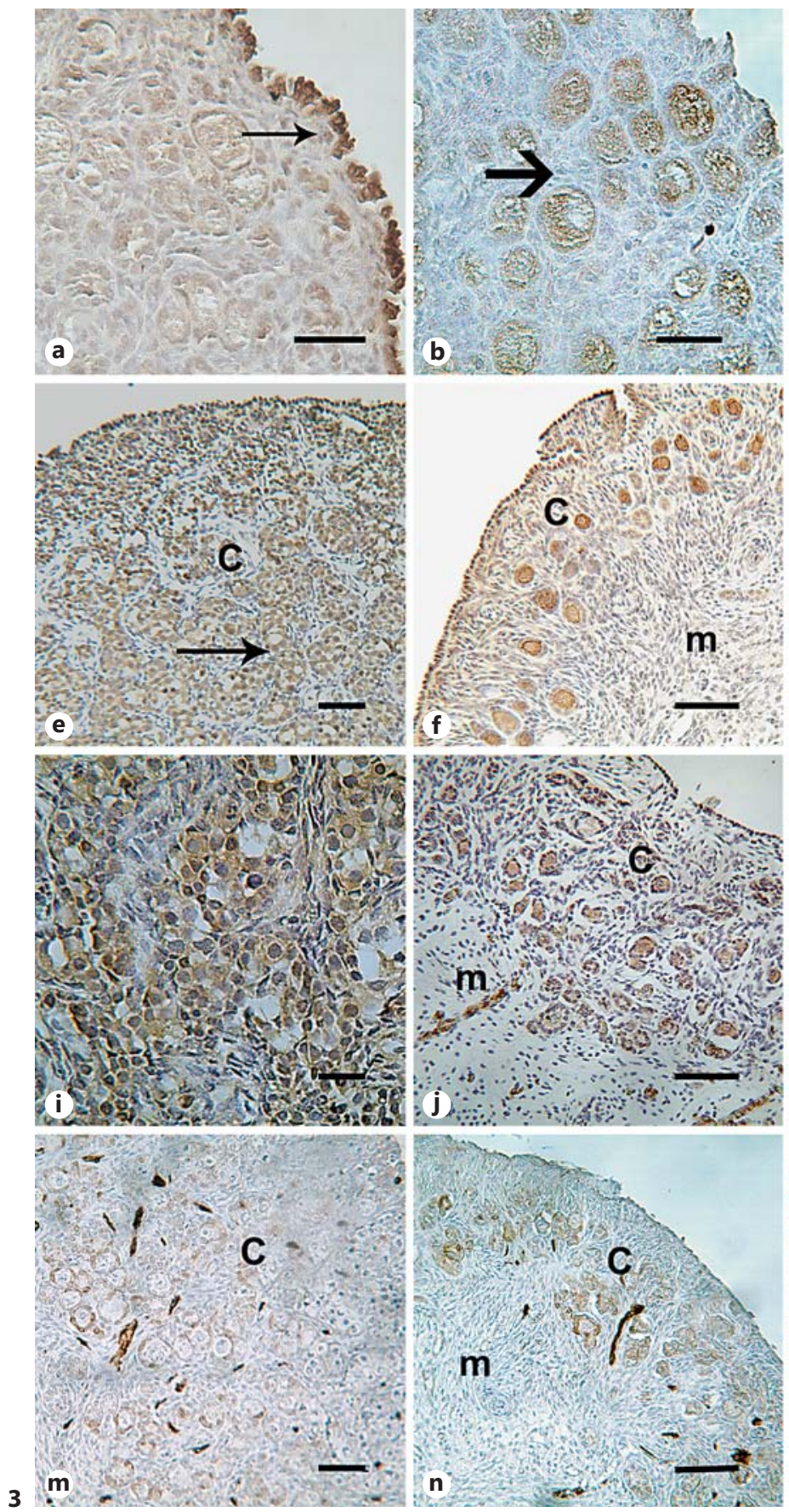

$\pi x^{2}$
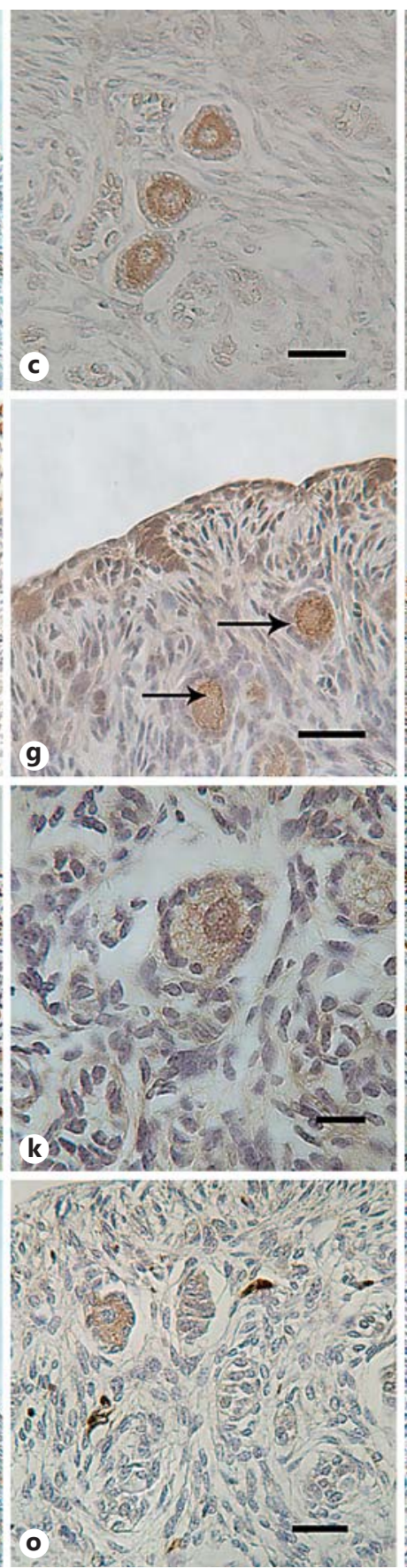
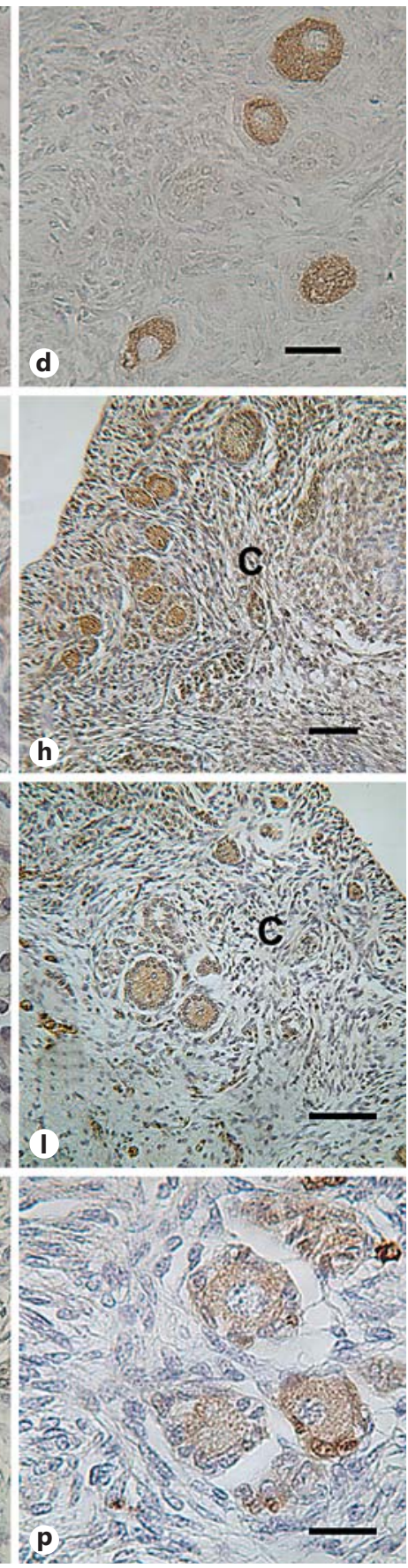

(For legend see next page.)

Kenngott/Sauer/Vermehren/Sinowatz 
Oct-3/4 protein was expressed in germ cells, located within the surface epithelium, as well as in oogonia/oocytes, enclosed in germ cell cords. The number of Oct-3/4-positive germ cells within the surface epithelium ascended to a CRL of $58.0 \mathrm{~cm}$. Immunostaining for Oct-3/4 increased from nonatretic primordial to secondary follicles, usually characterized by intensive staining of the cytoplasm of oocytes (fig. 3b-d). Selective expression of Oct-3/4 was observed in the nuclei of some oocytes. No reaction to Oct-3/4 was seen in the medulla or in medulla-associated structures. In atretic follicles (mostly seen from a CRL of $58.0 \mathrm{~cm}$ onwards in secondary to tertiary follicles), no reaction to Oct- $3 / 4$ could be detected.

In germ cell cytoplasm, the DDX4 protein was perceived during all stages of prenatal germ cell development (PGC in the surface epithelium, oogonia in the germ cell cords, follicular oocytes; fig. 3e, f). Only the intensity of DDX4 expression varied at different germ cell stages, being distinctly stronger in the oocyte cytoplasm compared to PGC located within the surface epithelium as well as in oogonia within the germ cell cords. In general, the intensity of immunostaining increased in the oocyte cytoplasm of healthy primordial to primary follicles in the investigated developmental stages (fig. 3g, h). The perinuclear cytoplasm showed especially intensive staining for DDX4 in single primary- and secondary-follicle oocytes. Frequently shrunken DDX4-negative oocytes of primary to tertiary follicles were seen at later developmental stages (CRL 58.0-94.0 cm). No reaction to DDX4 was observed in cortical and medulla stroma cells or in rete/tubular-like structures. An overview of the expression pattern of the used germ cell markers in the developing prenatal ovary is shown in table 4 .

\section{Immunostaining of S100 Beta and S100 Alpha}

Immunohistochemical analysis with the antibody against S100 alpha yielded a characteristic distribution pattern (fig. 3m). A distinct S100 alpha expression could be detected in the follicle cell whole cytoplasm of some primordial, primary, and secondary follicles (fig. 3n). Additionally, S100 alpha staining could be observed in the oocyte cytoplasm at different follicle stages (fig. 3o, p). In tertiary follicles, the basally lying cells showed a positive reaction to the antibody against $\mathrm{S} 100$ alpha. At later developmental stages, the $\mathrm{S} 100$ alpha staining of healthy oocytes (mostly of primordial and primary follicles) was weaker compared to that of S100 beta.

Immunohistochemical analysis with the antibody against S100 beta yielded a slightly different distribution
Fig. 3. a-p Immunohistochemically stained serial sections of various prenatal ovaries showing an overview of different expression patterns of ALPI, Oct-3/4, DDX4, and S100 beta as well as S100 alpha in prenatal bovine ovaries during different developmental stages. The cortex (c) and medulla ( $\mathrm{m}$ ) are labeled for orientation. a Section of the surface epithelium and the peripheral cortex of a fetus with a CRL of $34.0 \mathrm{~cm}$. Expression of ALPI is seen within the surface epithelium (arrow). Scale bar $=50 \mu \mathrm{m}$. Antibody against ALPI. b Section of the cortex of a fetus with a CRL of $44.0 \mathrm{~cm}$. Oct$3 / 4$ signals can be observed in the oocytes in primordial and primary follicles (arrow) lying adjacent to the surface epithelium. Scale bar $=50 \mu \mathrm{m}$. Antibody against Oct-3/4. c, d Section of the cortex of fetuses with CRL of 94.0 and $90.0 \mathrm{~cm}$. Oct-3/4 expression was detected in the cytoplasm of oocytes at different nonatretic follicle stages. Scale bars $=50 \mu \mathrm{m}$. Antibody against Oct-3/4. e Section of the cortex of a fetus with a CRL of $15.3 \mathrm{~cm}$. The PGC located in the surface epithelium as well as the oogonia of germ cell nests and germ cell cords (arrow) stained positive for DDX4. Scale bar $=80 \mu \mathrm{m}$. Antibody against DDX4. f Section of the cortex of a fetus with a CRL of $72.5 \mathrm{~cm}$. Note the strong DDX4-positive reaction in the oocytes of primordial and primary follicle stages. There are also DDX4-negative atretic follicle oocytes. Scale bar $=100 \mu \mathrm{m}$. Antibody against DDX4. g Section of the surface epithelium and cortex of a fetus with a CRL of $72.5 \mathrm{~cm}$. DDX-positive germ cells can be observed in the remaining germ cell cords. Note the positive oocytes of primary follicles (arrows). Scale bar $=50 \mu \mathrm{m}$. Antibody against DDX4. $\mathbf{h}$ Section of the surface epithelium and cortex of a fetus with a CRL of $90.0 \mathrm{~cm}$. Note the increased staining intensity for DDX4 in the cytoplasm of different follicle stages. Scale bar = $50 \mu \mathrm{m}$. Antibody against DDX4. i Section of the cortex of a fetus with a CRL of $15.30 \mathrm{~cm}$. Note the $\mathrm{S} 100$ beta expression in the oogonia cytoplasm in the prenatal bovine ovary germ cell cords. Scale bar $=50 \mu \mathrm{m}$. Antibody against S100 beta. $\mathbf{j}-\mathbf{I}$ Section of the cortex of fetuses with CRL of $66.0,52.0$, and $74.0 \mathrm{~cm}$. Strong specific $S 100$ beta expression was observed in the germ cell cytoplasm and nuclei, oogonia, and oocytes of different bovine ovaries follicle stages. Scale bars $=150 \mu \mathrm{m}(\mathbf{j}), 10 \mu \mathrm{m}(\mathbf{k})$, and $50 \mu \mathrm{m}(\mathbf{I})$. Antibody against S100 beta. $\mathbf{m}$ Section of the cortex of a fetus with a CRL of $31.0 \mathrm{~cm}$. S100 alpha-positive granulosa cells can be seen in primordial follicles detaching from the end of the germ cell cords. Scale bar $=50$ $\mu \mathrm{m}$. Antibody against S100 alpha. $\mathbf{n}$, o Section of the cortex of fetuses with CRL of 58.7 and $74.0 \mathrm{~cm}$. In the cortex of the prenatal bovine ovary, granulosa cells of different follicle stages show positive results for the antibody against $\mathrm{S} 100$ alpha in their cytoplasm. Furthermore, note the S100 alpha-positive cytoplasm of oocytes. Scale bars $=100 \mu \mathrm{m}(\mathbf{n})$ and $50 \mu \mathrm{m}(\mathbf{o})$. Antibody against S100 alpha. p Section of the cortex of a fetus with a CRL of $90.0 \mathrm{~cm}$. Note the strong S100 alpha-positive expression in granulosa cells and the S100 alpha cytoplasm staining of nonatretic oocytes. Scale bar $=50 \mu \mathrm{m}$. Antibody against S100 alpha. 


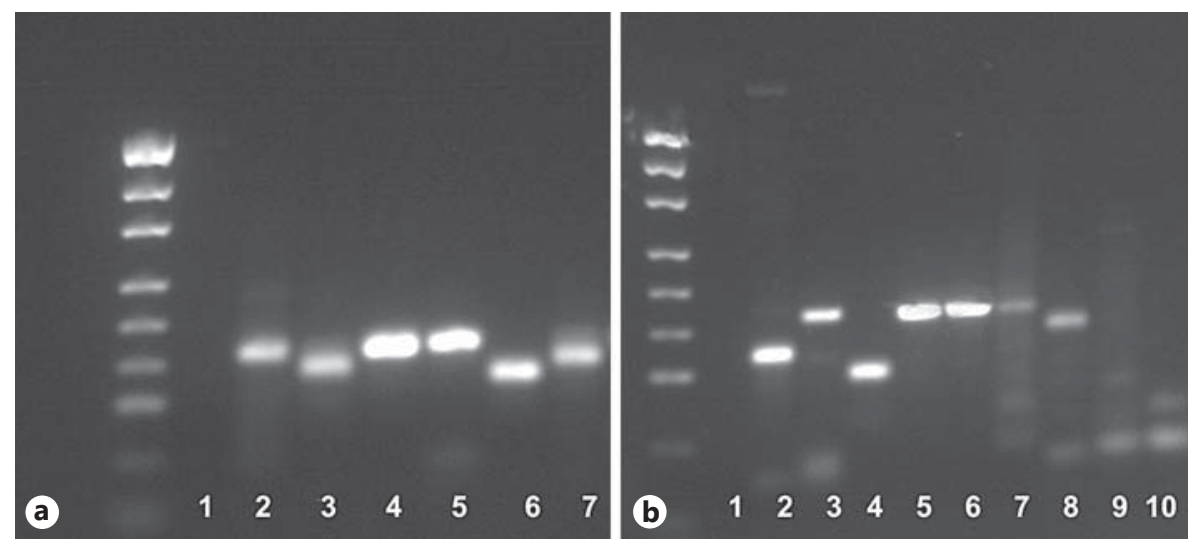

Fig. 4. Gel electrophoresis of amplification products from the laser-microdissected prenatal bovine tissue. a Marker (Peqlab); lane 1: water; lane 2: surface epithelium cells, K8 (148 bp); lane 3: surface epithelium cells, K18 (131 bp); lane 4: stroma cells under the surface epithelium, vimentin (150 bp); lane 5: germ cell cords, S100 beta (150 bp); lane 6: germ cell cords, S100 alpha (118 bp); lane 7: somatic cells of the germ cell cords, K18 (131 bp). b Marker (Peqlab), lane 1: water; lane 2: oocytes, S100 alpha (118

Table 4. Overview of the expression pattern of the germ cell markers used

\begin{tabular}{llll}
\hline $\begin{array}{l}\text { Expression pattern of the } \\
\text { antibodies against: }\end{array}$ & AP & Oct-3/4 & DDX4 \\
\hline $\begin{array}{llll}\text { PGC/oogonia } \\
\text { Oocytes }\end{array}$ & $\begin{array}{l}\text { positive } \\
\text { negative } \\
\text { Atretic oocytes }\end{array}$ & $\begin{array}{l}\text { positive } \\
\text { positive }\end{array}$ & $\begin{array}{l}\text { positive } \\
\text { positive } \\
\text { negative }\end{array}$ \\
\hline
\end{tabular}

pattern. At early stages of development, a weak expression of S100 beta was seen in the germ cells of germ cell cords (fig. 3i). The staining intensity within the primordial- and primary-follicle oocytes became stronger in older fetuses (from a CRL of $21.0 \mathrm{~cm}$ onwards), and the nuclei as well as the cytoplasm showed positive immunostaining with the antibody against S100 beta (fig. 3j-1). The oocytes of nonatretic secondary and single tertiary follicles were distinctly stained with the antibody against S100 beta at later stages (from $58.0 \mathrm{~cm}$ CRL onwards). Shrunken S100 alpha- and S100 beta-negative oocytes of primary to tertiary follicles were often seen at later developmental stages (CRL 58.0-94.0 cm).

Usually, antibodies against S100 alpha as well as S100 beta do not react in surface epithelium, stroma, or rete bp); lane 3: oocytes, S100 beta (150 bp); lane 4: oocytes, OCT4 (100 bp); lane 5: oocytes, DDX4 (150 bp); lane 6: stroma of the medulla, vimentin (150 bp); lane 7: rete ovarii with not significant product for K8; lane 8: rete ovarii with not significant and not distinct product for K18; lane 9: rete ovarii with not significant product for $\mathrm{K} 19$, and lane 10: rete ovarii with not significant product for K14.

ovarii. Vessel endothelium cells, however, demonstrated intensive S100 beta and S100 alpha expression. An overview of the S100 alpha and S100 beta staining pattern in the developing prenatal ovary is shown in table 5 .

\section{RT-PCR of LAM Prenatal Ovary Tissue Samples}

In the prenatal LAM tissue, a specific lane for the KRT8 and KRT18 transcript could be seen exclusively for surface epithelium cells. Additionally, specific lanes could be detected for the amplification products KRT8 and KRT18 in the somatic cells of germ cell cords as well as in the isolated follicular cells (fig. 4a). Vimentin expression was detected in the stroma directly under the surface epithelium and in the medulla stroma cells at all stages (fig. 4a). The germ cells of the cords as well as the oocytes showed the presence of RNA transcripts of DDX4 and OCT4 (fig. 4b). Furthermore, specific lanes for S100 alpha and S100 beta could be found exclusively in the microdissected germ cell of the cords (fig. 4a) and the follicle oocytes (fig. 4b). Not significant or not distinct band for K8, K14, K18, or K19 could be observed (fig. 4b) in the microdissected rete cells of all investigated developmental stages. An overview of the specific amplification products expressed in the LAM cell populations of prenatal ovaries is shown in table 6 . 
Table 5. Expression pattern of the antibodies against S100 alpha and S100 beta

\begin{tabular}{|c|c|c|}
\hline Expression pattern of the antibodies against: & S100 alpha & S100 beta \\
\hline$\underline{\text { Surface epithelium cells }}$ & negative & negative \\
\hline Somatic cells of the germ cell cords & negative & negative \\
\hline Stroma of the medulla & negative & negative \\
\hline Rete ovary & negative & negative \\
\hline Tubular-like structures & negative & negative \\
\hline Oocytes & + to +++ & $\begin{array}{l}+-/+(\mathrm{CRL} \leq 21.0 \mathrm{~cm}) ; \\
+/++(\mathrm{CRL} \geq 21.0 \mathrm{~cm}) \text { in primordial to primary } \\
\text { follicles; } \\
++/+++(\mathrm{CRL} \geq 58.0 \mathrm{~cm})\end{array}$ \\
\hline Atretic oocytes & negative & negative \\
\hline Follicle cells & $\begin{array}{l}++/+++ \text { follicle cells of primordial to secondary } \\
\text { follicles; } \\
++ \text { basal lying follicle cells of tertiary follicles }\end{array}$ & negative \\
\hline
\end{tabular}

\section{Discussion}

The general steps of the development of the fetal ovary have been described in different species such as bovines [van den Hurk et al., 1995; Burkhart et al., 2010; Kenngott et al., 2013], sheep [Sawyer et al., 2002], mice [Appert et al., 1998], and humans [Loffler et al., 2000]. In our study, the following Ks expression in prenatal bovine ovaries, could be observed: Ks were clearly detectable in the surface epithelial cell cytoplasm of the fetal bovine ovary from a CRL of $7.4 \mathrm{~cm}$ to a CRL of $58.0 \mathrm{~cm}$ (K19), to a CRL of $74.0 \mathrm{~cm}$ (K5, K7, K8 and K14), and to a CRL of $94.0 \mathrm{~cm}$ (K18), respectively. The presence of K8, K18, and K19 has already been reported in the coelomic epithelium of the gonad anlage of the mouse [Appert et al., 1998]. Our negative results for the investigated Ks in the cortex/medulla stroma cells are in agreement with the data of a previous study by Hummitzsch et al. [2013]. An interesting observation in our study is the strongly reduced or negative expression of K19 in the surface epithelial cells from a CRL of $58.0 \mathrm{~cm}$ onwards and of several other Ks (K5, K7, $\mathrm{K} 8$, and $\mathrm{K} 14$ ) from a CRL of $74.0 \mathrm{~cm}$ onwards. This is in striking contrast to the persistent K18 expression in the surface epithelium up to the latest fetus used in our study with a CRL of $94.0 \mathrm{~cm}$. The strongest $\mathrm{K}$ expression was usually seen in the multilayered areas of the surface epithelium. The cytoplasm of somatic germ cell cord cells showed a varying staining intensity, whereas in the single-layered surface epithelium regions K-negative cells could be regularly detected, intermingled with distinctly
Table 6. Overview of the specific amplification products expressed in the laser-assisted microdissected cell populations of the prenatal ovary

Surface epithelium cells

Somatic cells of the germ cell cords

K8, K18

Follicle cells

Stroma directly under the surface epithelium

Germ cells of the germ cell cords

Germ cells of the germ cell cords

Oocytes

Oocytes

Oocytes

Oocytes

$\mathrm{K} 8, \mathrm{~K} 18$

$\mathrm{K} 8, \mathrm{~K} 18$

Vim

S100 alpha

S100 beta

S100 alpha

S100 beta

OCT4

DDX4

Stroma of the medulla

Vim

Vim = Vimentin

positive cells. These findings complement the earlier results of previous studies [Sawyer et al., 2002; Burkhart et al., 2010; Kenngott et al., 2013] showing that open germ cell cord connections with the surface epithelium play an important role in the possible recruitment of somatic cells from the surface epithelium. Like Spanel-Borowski [2010], we assume that K-positive somatic sex cord cells are derived from K-positive surface epithelium. van den Hurk et al. [1995] also described positive K immunostaining in ovarian surface epithelium as well as in epithelial cord cells. Hummitzsch et al. [2013] also detected ovigerous cords composed of K18/19-positive gonadal 
ridge epithelial-like (GREL) cells intermingled with germ cells, which were in 'open' contact with the surface epithelium. A further important feature is that the somatic cells within the germ cell cords were positive for the K5, $\mathrm{K} 7, \mathrm{~K} 8, \mathrm{~K} 14, \mathrm{~K} 18$, and K19 proteins with different expression patterns. Further, a positive expression (K5, K8, K14, $\mathrm{K} 18$, and K19) in the follicular cell cytoplasm in primordial and primary follicles building on the end of the germ cell cords was observed in various quantities and intensities during the developmental stages. Appert et al. [1998] described irregularly formed ovigerous cords in the early mouse ovary, consisting of germ cells, and fibronectinnegative somatic cells expressing K8, K18, and K19. In accordance with our results, Appert et al. [1998] observed positive staining for Ks 8,18 , and 19 in the follicle cells of mouse primordial follicles; in contrast, later follicle stages expressed K8 and K18 but no K19. Using specific amplifications for KRT8 and 18, RT-PCR of LAM cells confirmed the results of immunohistochemistry. In line with Appert et al. [1998], we found distinct immunostaining for K18 in the follicle cells of all follicular stages. In agreement with Appert et al. [1998], we found that growing follicles lack K19. Hummitzsch et al. [2013] observed that K18/19 GREL cells are the only cell type beneath the germ cells inside the ovigerous cords and can be present as precursor cells of the later granulosa cells. van den Hurk et al. [1995] located K expression only in primordial follicle pregranulosa cells from ovaries aged between 3 and 7 gestational months. In contrast, we found positive immunostaining for Ks 5, 8, 14, 18, and 19 proteins in primordial and primary follicles of all stages up to a CRL of 94.0 $\mathrm{cm}$. Cells were negative (K7 and K19) or had different staining intensities and limited cell numbers $(\mathrm{K} 5, \mathrm{~K} 8$, and K14) at later follicle stages (secondary to antral follicles). In the tertiary follicles, we detected K18 staining mainly in the basal and follicular area. Loffler et al. [2000] detected expression of Ks in most primordial- and primaryfollicle cells, with no expression in the granulosa cells of growing multilayered follicles. In adult human and cow ovaries, Spanel-Borowski [2010] described a reduction of $\mathrm{K}$ expression in growing preantral follicles, whereas in antral follicles the basal follicular cells expressed $\mathrm{K}$ again. We found many DDX4-positive oogonia/oocytes in the dominant germ cell cords during the early developmental period but no DDX4-positive oocytes in the rete of bovine ovaries. Byskov and Lintern-Moore [1973] depicted oocytes within the fetal mouse rete ovarii. In our investigation, tubular-like structures/rete ovarii were often located near germ cell cords, being negative for all investigated Ks except for K8/18 staining. Furthermore, Hummitzsch et al. [2013] found no morphological signs that the rete ovarii is involved in or influenced by the follicle formation.

Based on the established expression pattern of the investigated Ks in surface epithelium cells, mainly in the multilayered areas, the somatic cells of the germ cell cords, and in the follicular cells of developing follicles, our data support the hypothesis [Everett, 1943; Motta and Makabe, 1982; Hummitzsch et al., 2013] that the surface epithelium can be regarded as the main origin of follicular cells. The mostly K-negative reaction (with the exception of a K8/18 protein expression) and not significant RT-PCR amplification products for K8, K14, or $\mathrm{K} 18$ in rete ovarii cells as well as the tubular-like structures also support this hypothesis. The strong staining for the different Ks could be observed mostly in the multilayered epithelium during the developing phase when germ cell cords are established. The expression of Ks in the surface epithelium also decreased (except for K18) during the developmental stages, with a less frequent occurrence of germ cell cords. Hummitzsch et al. [2013] supposed that some mesonephric surface epithelium cells change phenotype into GREL cells (among others, positive for cytokeratin 18/19), proliferate, and are intermingled by PGC. The underlying mesonephric surface basal lamina breaks down, following penetrating stroma from ovigerous cords (GREL cells together with germ cells) [Hummitzsch et al., 2013]. The positive Ks expression pattern, mainly in the (multilayered) surface epithelium, the germ cell cords, and the forming follicles in the bovine prenatal ovary, support the theory of Hummitzsch et al. [2013]. On the other hand, we cannot completely exclude the involvement of rete cells in follicular cell building because of the common expression of K8/18 staining in the surface epithelium, in follicular cells, and in the rete/tubular-like structure. On account of their K19 results and the close association of the rete and the sex cords, Loffler et al. [2000] supposed a double origin of the rete and the sex cord follicular cells. Further, in line with Hummitzsch et al. [2013], we cannot exclude that the rete ovarii could play a role in fetal or adult ovary paracrine regulation.

Furthermore, our results show that all investigated Ks are present in the various structures of the prenatal ovary in different manners, but only K18 yields a specific and disruptive expression pattern in specific ovarian tissue like the surface epithelium, the germ cell cords, and the developing follicle stages. In the adult bovine ovary, this result is similar to those of Wendl et al. [2012]. The expression pattern of the different Ks during ovary development confirms the results of Appert et al. [1998] in the 
mouse. Appert et al. [1998] assumed (in the mouse), along with Fridmacher et al. [1992] (in the rat), that K19 displays a development-dependent expression profile during ovary differentiation. The ongoing expression of K18 can be a specific event during differentiation of the prenatal bovine ovary as described in the testicular differentiation of the rat [Appert et al., 1998; Fridmacher et al., 1992].

In the ovary, positive vimentin staining has been observed in follicular cells lying in close contact to the follicular fluid [Czernobilsky et al., 1985; Santini et al., 1993; van Wezel et al., 1999]. Elongated granulosa cells with oblongated nuclei are suspected to undergo apoptosis [van den Hurk et al., 1992, 1995]. On the other hand, van den Hurk et al. [1995] also discovered elongated vimentin-positive granulosa cells with a round nucleus in nonatretic follicles. We found positive vimentin protein staining in the stromal cells of the ovary where, in line with van den Hurk et al. [1995], the bovine prenatal surface epithelium was negative for the vimentin protein at all investigated stages. In contrast, Santini et al. [1993] detected vimentin expression in ovarian surface epithelium. In agreement with van den Hurk et al. [1995], we localized a distinct positive reaction to the vimentin protein and amplification product in stroma cells underneath the surface epithelium and in the endothelium of blood vessels (immunohistochemistry) and stroma cells between the germ cell cords (immunohistochemistry). Similar to the study of van Wezel et al. [1999], in the adult ovary we detected a weak expression of vimentin in basally located follicular cells, a reduced or negative expression in intermediary-follicle cells, and distinct cytoplasmic staining in the follicular cells of tertiary follicles in the ovaries of fetuses with CRL of 58.0-94.0 cm. Follicular cells of the cumulus oophorus [in line with van Wezel et al., 1999] and corona radiata cells are strongly vimentin positive in prenatal ovaries. In the study of van den Hurk et al. [1995], the more peripheral follicular cells of the secondary and smaller antral follicles expressed vimentin but were negative in larger antral follicles while corona radiata cells were positive. van den Hurk et al. [1995] supposed that vimentin expression is correlated with mitosis, atresia, and intercellular activities in granulosa cells. Our earlier study [Kenngott et al., 2013] showed a low mitotic rate in somatic cells within the germ cell cords. This may be associated with the negative or weak vimentin-stained somatic cord cells in this study. In the same investigations of Kenngott et al. [2013], a substantial increase in the number of Ki-67-positive granulosa cells, confined to later follicle stages, was described in the prenatal ovary from a CRL of $58.0 \mathrm{~cm}$ onwards [Kenngott et al., 2013]. These results can correlate with vimentin-positive ovary granulosa cells of nonatretic follicles from a CRL of $58.0 \mathrm{~cm}$ onwards in the investigated sections.

Germ cells in the bovine fetal ovary are immunohistochemically visualized using antibodies against Oct-3/4, DDX4, and ALPI. Germ cells can be additionally identified by their characteristic morphology as described by Witschi [1948] in humans and Wrobel and Suss [1998] and Kenngott et al. [2013] in the prenatal bovine ovary. OCT3/4 are detected in early oocytes in the human ovary but become negative in germ cells during folliculogenesis [Stoop et al., 2005]. Hummitzsch et al. [2013] detected a nuclear OCT3/4 expression in PGC and inconsistent OCT3/4 staining in oogonia as well as follicular oocytes. Stoop et al. [2005] concluded that pluripotency is irreversibly lost by germ cells reaching meiosis and interacting with follicular cells. In contrast to these results, we found healthy oocytes of different follicle stages and various prenatal development phases displaying distinct cytoplasmic immunostaining for Oct-3/4. This agrees with results in the mouse, where ОСТ $3 / 4$ expression in oocytes is regularly found after completion of the prophase of meiosis I [Pesce et al., 1998].

Wrobel and Suss [1998] described AP-positive cells in early embryos not only as preliminary stages of the PGC but also as pluripotent hematopoietic stem cells. Therefore, for localization of PGC in our study we used the ALPI protein as a marker for PGC; AP in humans has been shown, among others, to be expressed in PGC, some primary oocytes, and the theca of Graafian follicles during the early gestation period [Pinkerton et al., 1961]. We found that, in the fetal bovine ovary, ALPI expression is usually confined to PGC located within the surface epithelium and to oogonia of the germ cell nest and germ cell cords, which is in agreement with the findings of Stoop et al. [2005] that showed the highest AP expression in cortex PGC with decreasing intensity with increasing age. In addition, in humans, Garattini et al. [1985] could show that human placental AP is also present in the liver and intestine. In our study, we could show that ALPI (compare antibody) is specifically expressed in the early germ cells of prenatal bovine ovaries. In line with Castrillon et al. [2000], Stoop et al. [2005], and Hummitzsch et al. [2013], we found DDX4 expression in the cytoplasm of oogonia and oocytes.

Hummitzsch et al. [2013] described DDX-positive oogonia as well as oocytes. In agreement with Castrillon et al. [2000] and Stoop et al. [2005], the expression intensity of DDX4 was stronger in oocytes compared to earlier 
germ cells. In our investigation, the expression intensity increased in the nonatretic oocytes of primordial and primary follicles at the investigated stages, and also a specific amplification product for DDX4 could be found in microdissected prenatal oocytes. We could also confirm the observation of Hickford et al. [2011] that a strong DDX4positive perinuclear body occurs in some oocytes. In humans, the circumscribed DDX4-positive area in germ cells was identified as the Balbiani body [Albamonte et al., 2008], a temporary local aggregation of various cell organelles, like mitochondria and ribosomes, which are found in the germ cells of many vertebrates. In agreement with Hickford et al. [2011], we suppose that the DDX4 protein is necessary for germ cell proliferation and differentiation. In line with the findings of Stoop et al. [2005] in the human ovary, we think DDX4 can be a useful marker for intact germ cells at all stages of fetal ovary development. Our findings clearly demonstrate an overlapping expression pattern of the 3 investigated germ cell antibodies during the prenatal development of ovaries. These results are in agreement with Kerr et al. [2008], who described coexpression of different pluripotent stem cell markers during early germ cell development. In addition to our immunohistochemical data, RT-PCR confirmed the expression of mRNA for DDX4 and OCT4 in oocytes isolated by LAM.

A further interesting finding is the different expression of S100 alpha and beta in the germ cell cords and oocytes of prenatal ovaries. S100 beta was found in germ cells of cords and nonatretic oocytes with an increasing staining intensity in bovine fetuses with a CRL of up to $94.0 \mathrm{~cm}$. Immunostaining for $\mathrm{S} 100$ beta could be observed in the nuclei and cytoplasm of oocytes in primordial, primary, and later follicle stages (in fetuses with a CRL above 58.0 $\mathrm{cm})$. Negative oocytes could also be detected. In the follicle cells, S100 alpha expression could be frequently observed in the granulosa cells of primordial to secondary follicles as well as in the basally lying tertiary follicles cells. Additionally, staining of the cytoplasm of oocytes of different follicle stages could be seen. Further specific PCR products for S100 alpha and S100 beta could be detected in the microdissected oocytes. S100 has previously been found in human oocytes and granulosa cells of primordial follicles [Haimoto et al., 1987] as well as in germ cell cords and bovine follicle oocytes and the follicles of prenatal ovaries [Kenngott et al., 2013]. In the present study, we found that $\mathrm{S} 100$ beta was much more prominent in oocytes than S100 alpha, while oocytes of atretic follicles were negative for both.

\section{Acknowledgements}

We would like to express our thanks to Prof. Francis Zichy for language editing, to Ms. Gabriele Russmeier for valuable assistance with immunohistochemical studies, to Ms. Angela Servatius for molecular biological laboratory support, to Mrs. Christel Schura for her technical guidance, and to Prof. Dr. Sutter (Institute for Infectious Diseases and Zoonoses, Ludwig Maximilian University) for providing us with a UV transilluminator (Biostep).

\section{References}

Abrahamsen H.N., T. Steiniche, E. Nexo, S.J. Hamilton-Dutoit, B.S. Sorensen (2003) Towards quantitative mRNA analysis in paraffin-embedded tissues using real-time reverse transcriptase-polymerase chain reaction: a methodological study on lymph nodes from melanoma patients. J Mol Diagn 5: 34-41.

Albamonte M.S., M.A. Willis, M.I. Albamonte, F. Jensen, M.B. Espinosa, A.D. Vitullo (2008) The developing human ovary: Immunohistochemical analysis of germ-cell-specific VASA protein, BCL-2/BAX expression balance and apoptosis. Hum Reprod 23: 18951901.

Appert A., V. Fridmacher, O. Locquet, S. Magre (1998) Patterns of keratins 8, 18 and 19 during gonadal differentiation in the mouse: sex- and time-dependent expression of keratin 19. Differentiation 63: 273-284.

Aumuller G., C. Schulze, C. Viebahn (1992) Intermediate filaments in Sertoli cells. Microsc Res Tech 20: 50-72.
Burkhart M.N., J.L. Juengel, P.R. Smith, D.A. Heath, G.A. Perry, M.F. Smith, H.A. Garverick (2010) Morphological development and characterization of aromatase and estrogen receptors alpha and beta in fetal ovaries of cattle from days 110 to 250. Anim Reprod Sci 117: 43-54.

Byskov A.G. (1980) Sexual differentiation of the mammalian ovary; in Motta P.M., E.S.E. Hafez (eds): Biology of the Ovary. The Hague, Nijhoff.

Byskov A.G. (1986) Differentiation of mammalian embryonic gonad. Physiol Rev 66: 71-117.

Byskov A.G., S. Lintern-Moore (1973) Follicle formation in the immature mouse ovary: the role of the rete ovarii. J Anat 116: 207-217.

Castrillon D.H., B.J. Quade, T.Y. Wang, C. Quigley, C.P. Crum (2000) The human vasa gene is specifically expressed in the germ cell lineage. Proc Natl Acad Sci USA 97: 95859590.
Czernobilsky B., R. Moll, R. Levy, W.W. Franke (1985) Co-expression of cytokeratin and vimentin filaments in mesothelial, granulosa and rete ovarii cells of the human ovary. Eur J Cell Biol 37: 175-190.

Everett N.B. (1943) Observations and experimental evidence relating to the origin and differentiation of the definitive germ cells in mice. J Exp Zool 92: 49-91.

Fortune J.E. (2003) The early stages of follicular development: activation of primordial follicles and growth of preantral follicles. Anim Reprod Sci 78: 135-163.

Franke W.W., C. Grund, E. Schmidt (1979) Intermediate-sized filaments present in Sertoli cells are of the vimentin type. Eur J Cell Biol 19: 269-275.

Franke W.W., D.L. Schiller, R. Moll, S. Winter, E. Schmid, I. Engelbrecht, H. Denk, R. Krepler, B. Platzer (1981) Diversity of cytokeratins: differentiation specific expression of cytokeratin polypeptides in epithelial cells and tissues. J Mol Biol 153: 933-959. 
Franke. W. W., E. Schmid, M. Osborn, K. Weber, K. (1978) Different intermediate-sized filaments distinguished by immunofluorescencemicroscopy. Proc Natl Acad Sci USA 75: 5034-5038.

Franke W.W., E. Schmid, D.L. Schiller, S. Winter, E.D. Jarasch, R. Moll, H. Denk, B.W. Jackson, K. Illmensee (1982) Differentiation-related patterns of expression of proteins of intermediate-size filaments in tissues and cultured cells. Cold Spring Harb Symp Quant Biol 46: 431-453.

Fridmacher V., O. Locquet, S. Magre (1992) Differential expression of acidic cytokeratins 18 and 19 during sexual differentiation of the rat gonad. Development 115: 503-517.

Gabbiani G., Y. Kapanci, P. Barazzone, W.W. Franke (1981) Immunochemical identification of intermediate-sized filaments in human neoplastic cells: a diagnostic aid for the surgical pathologist. Am J Pathol 104: 206216.

Gall L., V. De Smedt, S. Ruffini (1992) Co-expression of cytokeratins and vimentin in sheep cumulus-oocyte complexes: alteration of intermediate filament distribution by acrylamide. Dev Growth Differ 34: 579-587.

Garattini E., J. Margolis, E. Heimer, A. Felix, S. Udenfriend (1985) Human placental alkaline phosphatase in liver and intestine. Proc Natl Acad Sci USA 82: 6080-6084.

Gjerdrum L.M., S. Hamilton-Dutoit (2005) Laser-assisted microdissection of membranemounted sections following immunohistochemistry and in situ hybridization. Methods Mol Biol 293: 139-149.

Goldmann R., A. Goldman, K. Green, J. Jones, S. Jones, H. Yang (1986) Intermediate filament networks: organization and possible functions of a diverse group of cytoskeletal elements. J Cell Sci Suppl 5: 69-97.

Gondos B., L. Zamboni (1969) Ovarian development: the functional importance of germ cell interconnections. Fertil Steril 20: 176-189.

Gould V.E. (1985) The coexpression of distinct classes of intermediate filaments in human neoplasms. Arch Pathol Lab Med 109: $984-$ 985.

Haimoto H., S. Hosoda, K. Kato (1987) Differential distribution of immunoreactive S100-alpha and S100-beta proteins in normal nonnervous human tissues. Lab Invest 57: 489498.

Hickford D.E., S. Frankenberg, A.J. Pask, G. Shaw, M.B. Renfree (2011) DDX4 (VASA) is conserved in germ cell development in marsupials and monotremes. Biol Reprod 85: 733-743.

Hummitzsch K., H.F. Irving-Rodgers, N. Hatzirodos, W. Bonner, L. Sabatier, D.P. Reinhardt, Y. Sado, Y. Ninomiya, D. Wilhelm, R.J. Rodgers (2013) A new model of development of the mammalian ovary and follicles. PLoS One 8: e55578.
Jackson B.W., C. Grund, S. Winter, W.W. Franke, K. Illmensee (1981) Formation of cytoskeletal elements during mouse embryogenesis. 2. Epithelial differentiation and intermediate-sized filaments in early postimplantation embryos. Differentiation 20: 203-216.

Jost A., B. Vigier, J. Prepin, J.P. Perchellet (1973) Studies on sex differentiation in mammals. Recent Prog Horm Res 29: 1-41.

Karlson P., D. Doenecke, J. Koolmann, G. Fuchs, W. Gerok, R. Hammelehle (2005) Karlsons Biochemie und Pathobiochemie. Stuttgart, Thieme.

Kenngott, R.A., A. Al-Banaw, M. Vermehren, J. Wendl, F. Sinowatz (2010) Application of laser-assisted microdissection for gene expression analysis of mammalian germ cells. Anat Histol Embryol 39:219-226.

Kenngott R.A., F. Sinowatz (2007) Prenatal development of the bovine oviduct. Anat Histol Embryol 36: 272-283.

Kenngott R.A., F. Sinowatz (2008) Expression and distribution of intermediate-filament proteins and laminin during the development of the bovine Müllerian duct. Anat Histol Embryol 367: 223-230.

Kenngott R.A., M. Vermehren, K. Ebach, F. Sinowatz (2013) The role of ovarian surface epithelium in folliculogenesis during fetal development of the bovine ovary: a histological and immunohistochemical study. Sex Dev 7: 180-195.

Kenngott R.A., M. Vermehren, U. Sauer, K. Ebach, F. Sinowatz (2011) Cellular expression and localization of estrogen receptor alpha and progesterone receptor mRNA in the bovine oviduct combining laser-assisted microdissection, quantitative PCR, and in situ hybridization. J Histochem Cytochem 59: 312327.

Kerr C.L., C.M. Hill, P.D. Blumenthal, J.D. Gearhart (2008) Expression of pluripotent stem cell markers in the human fetal ovary. Hum Reprod 23: 589-599.

Lazarides E. (1980) Intermediate filaments as mechanical integrator of cellular shape. Nature 283: 249-256.

Lazarides E., D.R. Balzer (1987) Specificity of desmin to avian and mammalian muscles cells. Cell 14: 429-438.

Lehmann U., H. Kreipe (2006) Laser-assisted microdissection and isolation of DNA and RNA. Methods Mol Med 120: 65-75.

Loffler S., L.C. Horn, W. Weber, K. SpanelBorowski (2000) The transient disappearance of cytokeratin in human fetal and adult ovaries. Anat Embryol 201: 207-215.

Mauleon P. (1969) Oogenesis and folliculogenesis; in Cole H., P. Cupps (eds): Reproduction in Domestic Animals. New York, Academic Press, pp 187-215.

McGee E.A., S.Y. Hsu, A. Kaipia, A.J. Hsueh (1998) Cell death and survival during ovarian follicle development. Mol Cell Endocrinol 140: $15-18$
McNutt M.A., J.W. Bolen, A.M. Gown, S.P. Hammar, A.M. Vogel (1985) Coexpression of intermediate filaments in human epithelial neoplasms. Ultrastruct Pathol 9: 31-43.

Miettinen M., V.P. Lehto, I. Virtanen (1984) Antibodies to intermediate filament proteins in the diagnosis and classification of human tumors. Ultrastruct Pathol 7: 83-107.

Mirecka J., U. Brinck, M. Korabiowska, A. Schauer (1994) Localization of S-100 protein in pig ovarian structures. Folia Histochem and $\mathrm{Cy}$ tobiol 32: 177-180.

Moll R., W.W. Franke, D.L. Schiller, B. Geiger, R. Krepler (1982) The catalog of human cytokeratins: patterns of expression in normal epithelia, tumors and cultured cells. Cell 31: $11-24$.

Mosimann W., T. Kohler (1990) Zytologie, Histologie und mikroskopische Anatomie der Haussäugetiere. Berlin, Parey.

Motta M., S. Makabe (1982) Development of the ovarian surface and associated germ cells in the human fetus. Cell Tissue Res 226: 493-510.

Motta P.M., S.A. Nottola, S. Makabe (1997) Natural history of the female germ cell from its origin to full maturation through prenatal ovarian development. Eur J Obstet Gynecol Reprod Biol 75: 5-10.

Mulisch M., U. Welsch (2010) Romeis mikroskopische Technik, ed 18. Heidelberg, Spektrum.

Murray G.I. (2007) An overview of laser microdissection technologies. Acta Histochem 109: 171-176.

Noll S., S. Schaub-Kuhnen (2000) Praxis der Immunhistochemie. Munich, Urban \& Fischer.

Pereda J., T. Zorn, M. Soto-Suazo (2006) Migration of human and mouse primordial germ cells and colonization of the developing ovary: an ultrastructural and cytochemical study. Microsc Res Tech 69: 386-395.

Pesce M., X. Wang, D.J. Wolgemuth, H. Scholer (1998) Differential expression of the OCT-4 transcription factor during mouse germ cell differentiation. Mech Dev 71: 89-98.

Pinkerton J.H., McKay D.G., E.C. Adams, A.T. Hertig (1961) Development of the human ovary - a study using histochemical technics. Obstet Gynecol 18: 152-181.

Ricken A.M., K. Spanel-Borowski, M. Saxer, P.R. Huber (1995) Cytokeratin expression in bovine corpora lutea. Histochem Cell Biol 103: 345-354.

Rüsse I., F. Sinowatz (1998) Lehrbuch der Embryologie der Haustiere. Berlin, Parey.

Santini D., C. Ceccarelli, G. Mazzoleni, G. Pasquinelli, V.M. Jasonni, G.N. Martinelli (1993) Demonstration of cytokeratin intermediate filaments in oocytes of the developing and adult human ovary. Histochemistry 99: 311319.

Sawyer H.R., P. Smith, D.A. Heath, J.L. Juengel, S.J. Wakefield, K.P. McNatty (2002) Formation of ovarian follicles during fetal development in sheep. Biol Reprod 66: 1134-1150. 
Spanel-Borowski K. (2010) Footmarks of innate immunity in the ovary and cytokeratin-positive cells as potential dendritic cells. Berlin, Springer.

Steinert P.M., J.C.R. Jones, R.D. Jones (1984) Intermediate filaments. J Cell Biol 99: 22-27.

Stoop H., F. Honecker, M. Cools, R. de Krijger, C. Bokemeyer, L.H. Looijenga (2005) Differentiation and development of human female germ cells during prenatal gonadogenesis: an immunohistochemical study. Hum Reprod 20: 1466-1476.

Tanaka Y., K. Nakada, M. Moriyoshi, Y. Sawamukai (2001) Appearance and number of follicles and change in the concentration of serum FSH in female bovine fetuses. Reproduction 121: 777-782.

van den Hurk R., G. Dijkstra, F.N. van Mil, S.C. Hulshof, T.S. van den Ingh (1995) Distribution of the intermediate filament proteins vimentin, keratin, and desmin in the bovine ovary. Mol Reprod Dev 41: 459-467. van den Hurk R., E.R. Spek, G. Dijkstra, C.J. van Vorstenbosch, S.C. Hulshof, S.J. Dieleman (1992) Effect of pregnant mares' serum gonadotrophin on the micromorphology of antral follicles in heifers, with special reference to atypical granulosa cells. J Reprod Fertil 95: 903-913.

Vanstapel M.J., K.C. Gatter, C. de Wolf-Peeters, D.Y. Mason, V.D. Desmet (1986) New sites of human S-100 immunoreactivity detected with monoclonal antibodies. Am J Clin Pathol 85: 160-168.

van Wezel I.L., M. Krupa, R.J. Rodgers (1999) Development of the membrana granulosa of bovine antral follicles: structure, location of mitosis and pyknosis, and immunolocalization of involucrin and vimentin. Reprod Fertil Dev 11: 37-48.

Viale G., M. Gambacorta, P. Dellòrto, G. Coggi (1988) Coexpression of cytokeratins and vimentin in common epithelial tumours of the ovary: an immunocytochemical study of eighty-three cases. Virchows Archiv A Pathol Anat 413: 91-101.
Wartenberg H., B. Hilscher, W. Hilscher (1998) Germ cell kinetics during early ovarian differentiation: an analysis of the oogonial cell cycle and the subsequent changes in oocyte development during the onset of meiosis in the rat. Microsc Res Tech 40: 377-397.

Wendl J., K. Ebach, D. Rodler, R.A. Kenngott (2012) Immunocytochemical localization of cytoplasmic and nuclear intermediate filaments in the bovine ovary during folliculogenesis. Anat Histol Embryol 41: 190-201.

Witschi E. (1948) Migration of the germ cells of human embryos from the yolk sac to the primitive gonadal fold. Contrib Embryol 32: 67-80.

Wrobel K.H., Suss F. (1998) Identification and temporospatial distribution of bovine primordial germ cells prior to gonadal sexual differentiation. Anat Embryol (Berl) 197: 451-467. 